Cibele Monteiro?

Ohttps://orcid.org/0000-0002-3492-7811

Emanuella Tavares

Ohttps:/orid.org/0000-0003-4823-0211

Alice Câmara

Ohttps://orid.org/0000-0002-1974-4363

Jonas Nobre'

Ohttps://orcid.org/0000-0003-1646-921X

\section{Regulação molecular do ritmo circadiano e transtornos psiquiátricos: uma revisão sistemática}

\author{
Molecular regulation of circadian rhythm and \\ psychiatric disorders: a systematic review
}

DOI: $10.1590 / 0047-2085000000258$

\section{RESUMO}

Objetivo: $\bigcirc$ artigo possui como objetivo investigar os genes relógio que estão mais associados com os transtornos psiquiátricos, as funções e localizações desses genes, assim como investigar o principal transtorno, método e modelo considerados nas análises. O trabalho busca resumir os achados e discutir o impacto dessas pesquisas no conhecimento científico. Métodos: Esta revisão utilizou-se de uma metodologia sistemática (Prospero; ID 152031) e seguiu as diretrizes PRISMA. A busca dos estudos foi realizada nas bases de dados PubMed/MEDLINE e Scientific Eletronic Library Online e foram utilizados os termos do Medical Subject Headings Terms. Foram selecionados estudos quantitativos com resultados conclusivos referentes à associação de transtornos psiquiátricos com a regulação molecular do ritmo circadiano. As informações úteis foram extraídas e utilizadas para a elaboração de gráficos e tabelas. Resultados: Foram incluídos 24 artigos em nosso estudo. Observou-se que o transtorno bipolar consistiu no transtorno psiquiátrico mais abordado (40\% dos estudos); a nacionalidade polonesa dos participantes também se destacou em 39\% dos trabalhos. Adicionalmente, o gene PER foi o mais estudado (25\%) e o córtex cerebral foi a principal região em que os genes relógio avaliados se expressam (34\%). A PCR comum mostrou ser o método mais utilizado (38\%) e o metabolismo da serotonina mostrou ser a principal função desempenhada pelos produtos gênicos (16\%). Conclusões: Em conjunto, os resultados sugerem que o transtorno bipolar consiste no distúrbio psiquiátrico mais prevalente entre as pesquisas relacionadas aos genes circadianos, expressos principalmente no córtex cerebral de humanos, em especial o gene PER.

\section{PALAVRAS-CHAVE}

Transtorno psiquiátrico, ritmo circadiano, genes relógio.

\begin{abstract}
Objective: The article aims to investigate the clock genes that are most associated with psychiatric disorders, the functions, and locations of these genes, as well as to investigate the main disorder, method and model in the analyzes. The paper seeks to summarize the findings and discuss the impact of this research on scientific knowledge. Methods: This review used a systematic methodology (Prospero; ID 152031) and followed the PRISMA guidelines. The studies were searched in the PubMed/MEDLINE and Scientific Electronic Library Online databases and the terms of the Medical Subject Headings Terms were used. Quantitative studies with conclusive results regarding the association of psychiatric disorders with the molecular regulation of circadian rhythm were selected. The useful information was extracted and used for the elaboration of graphs and tables. Results: We included 24 articles in our study. Bipolar disorder was the most commonly addressed psychiatric disorder (40\% of studies); The participants' Polish nationality also stood out in 39\% of the works. Additionally, the PER gene was the most studied (25\%) and the cerebral cortex was the main region in which the evaluated clock genes express themselves (34\%). Finally, common PCR was the most used method (38\%) and serotonin metabolism was the main function performed by gene products (16\%). Conclusions: Taken together, the results suggest that bipolar disorder is the most prevalent psychiatric disorder among research related to circadian genes, expressed mainly in the cerebral cortex of humans, especially the PER gene.
\end{abstract}

\section{KEYWORDS}

Psychiatric disorder, circadian rhythm, clock genes. 


\section{INTRODUÇÃO}

Os organismos vivos herdam os genes relógio, que podem se alterar de acordo com os ciclos ambientais. Esses genes interagem com diversos fatores ambientais e regulam o comportamento e a fisiologia dos organismos vivos'. De acordo com o período do dia, o mecanismo dos genes envolvidos na regulação do ciclo circadiano (genes relógio) gera um ritmo sazonal, ajustando-se às mudanças no fotoperíodo². Diante disso, esses genes relógio exercem uma influência direta no "relógio biológico". O termo "relógio biológico" pode ser definido como o conjunto de mecanismos intrínsecos ao organismo que conferem ritmicidade aos processos fisiológicos. Os ritmos biológicos são chamados de ritmos circadianos e podem ser eventos importantes para a sobrevivência ${ }^{3}$. A geração desses ritmos no organismo é conferida pela expressão de proteínas advindas de genes relógio, sendo aquelas codificadas em intervalos bem definidos ao longo de 24 horas. Ainda que haja um caráter endógeno nos ritmos do organismo, incide também sobre eles a influência de marcadores externos/ambientais, que atuam na sincronização desses ritmos. Esses marcadores podem ser de várias naturezas, mas os que mais predominam são o ciclo claro/ escuro e a disponibilidade de alimentos ${ }^{3}$.

Uma região diretamente envolvida com os ritmos biológicos é o núcleo supraquiasmático (NSQ). Desde 1960, o NSQ tem sido apontado como forte candidato a marca-passo central do sistema de temporização em mamíferos ${ }^{4}$. Esse achado foi confirmado em 1980, quando foi demonstrado que transplantes do NSQ fetal permitem recuperar a ritmicidade circadiana de animais tornados arrítmicos em consequência da lesão bilateral do NSQ. Localizado bilateralmente ao hipotálamo, esse núcleo recebe informação luminosa através do feixe retino-hipotalâmico e, a partir daí, passa a coordenar a expressão dos genes relógio, bem como a sincronização temporal interna do corpo. Uma harmonização bem estabelecida entre os ciclos ambientais e o sistema de temporização endógeno é de caráter fundamental para a sobrevivência do organismo, pois confere a ele a capacidade de prever e antecipar eventos como o sono e a fome ${ }^{4}$.

A harmonia entre a manutenção do ritmo endógeno e a sincronização por fatores como o ciclo claro/escuro começou a ser estudada por Jean Jaques de Mairan em 1729, que observou o fenômeno periódico das folhas de Mimosa pudica ${ }^{5}$. Percebeu-se que o ritmo biológico persiste mesmo na ausência de sinais externos. Mairan condicionou a planta a um estado de iluminação constante e viu que os movimentos de suas folhas continuavam alternando ciclicamente durante o dia. Por sua vez, De Candolle conseguiu retratar, em 1835, a harmonia entre a manutenção do ritmo endógeno e a sincronização por fatores como o ciclo claro/ escuro, observando que a Mimosa diminuía seu ritmo foliar às 22 horas em ausência de luz e o ajustava às 24 horas com o estímulo luminoso ${ }^{5}$. Desde o século XIX, os estudos sobre ritmos biológicos e sua manutenção molecular têm avançado, mas foi especialmente nas últimas quatro décadas que eles conquistaram notório reconhecimento e espaço na pesquisa científical ${ }^{1-7}$.

Nesse contexto, é fundamental avaliar as relações existentes entre a regulação dos ritmos biológicos e os diversos transtornos psiquiátricos. As doenças psiquiátricas são complexas e podem depender de diversos genes e de suas interações potenciais, a exemplo dos genes envolvidos no ritmo circadiano?. Nesse contexto, distúrbios na sincronização dos ritmos biológicos podem levar a problemas de ordem fisiológica e comportamental, tais como doenças psiquiátricas ${ }^{8}$. Problemas de caráter social estão fortemente associados à causa da maioria dos transtornos psiquiátricos, incluindo depressão, transtorno bipolar (TB), esquizofrenia e autismo9. Alguns aspectos da vida moderna, como o trabalho em turnos rotativos, impõem estresse aos indivíduos ao interromper seus ritmos circadianos. O distúrbio do ritmo circadiano tem sido implicado em uma variedade de transtornos psiquiátricos, incluindo depressão e ansiedade. Acredita-se que esse distúrbio esteja subjacente aos principais sintomas do transtorno depressivo maior (TDM), a saber, alterações de humor e anedonia ${ }^{8}$. Um estudo associou o trabalho por turnos a desfechos adversos de saúde mental em enfermeiras, um grupo demográfico chave que realiza trabalhos por turnos. Atualmente, por não se ter esclarecido o caráter hereditário de tais alterações, não se sabe claramente se filhos de mulheres que realizam trabalhos por turnos durante a gravidez são mais suscetíveis a desenvolver transtornos mentais mais tarde na vida.

Adicionalmente, os distúrbios do sono são comuns em pacientes diagnosticados com transtornos psiquiátricos ${ }^{7}$. A prevalência de insônia ou sonolência excessiva durante o curso do transtorno sugeriu um papel fundamental do sistema circadiano no desenvolvimento dessas desordens ${ }^{7}$. Portanto, o tratamento de distúrbios do sono deve ser paralelo à terapia dos transtornos psiquiátricos, tais como a depressão e a ansiedade. Essa abordagem terapêutica pode resultar em uma remissão mais rápida, com redução do risco de tentativas de suicídio7. Em 2013, foi publicado o papel de fatores não genéticos agindo de forma direta e indiretamente no comportamento suicida ${ }^{10,11}$. Por outro lado, Pawlak et al. relatam a relação dos polimorfismos dos genes TPH1, TPH2, $5 H T 2 A, C R H R 1$ e ACP1 com esse comportamento ${ }^{12}$. Adicionalmente, estudos têm relatado que fatores ambientais atrelados a contextos hereditários estão interligados à predisposição ao suicídio, sendo o diagnóstico do comportamento suicida um fator bastante complexo ${ }^{13}$. Dessa forma, análises utilizando fenótipos intermediários hereditários são estratégias promissoras para identificar associações genéticas reais ${ }^{14}$. Pesquisas mostram que o comportamento suicida e o TB podem estar interligados por uma perturbação circadiana e ritmos sazonais ${ }^{15,16}$. Além disso, foi confirmada a associação 
entre as variantes dos genes relógio CLOCK e TIMELESS e o número de tentativas de suicídio ${ }^{10}$.

Estudos genômicos sugerem que as variações nos genes relógio estão fortemente associadas com neuropsiquiatria humana ${ }^{17}$. O gene PER3 faz parte da família dos genes relógio de humanos, os quais são responsáveis por codificar componentes dos ritmos circadianos, de atividade locomotora, metabolismo e comportamento. Nos últimos anos, vêm sendo realizados estudos que avaliam a associação de diferentes polimorfismos do gene PER3 com transtornos do sono e com transtornos de humor ${ }^{18}$. Recentemente, o gene SIRT1 foi descrito como uma molécula importante nos mecanismos dos ritmos circadianos. Esse gene relógio forma um complexo com BMAL1 e desempenha um papel fundamental no mecanismo de feedback para a manutenção do ciclo circadiano ${ }^{19-23}$. Adicionalmente, alguns estudos envolvendo os genes PROKR2 e CLOCK indicam uma relação deles com os transtornos psiquiátricos ${ }^{19-23}$. Um trabalho recente relatou que a região SIRT1 desempenha um papel importante no ciclo circadiano, possuindo ainda uma relação com o metabolismo dopaminérgico ${ }^{24}$. Por fim, o transtorno afetivo sazonal (TAS) consiste em uma condição de mudanças sazonais de humor caracterizadas por depressão recorrente no outono ou inverno que remitem espontaneamente na primavera ou no verão. A interação dos genes CLOCK e ARNTL contribui para a suscetibilidade ao TAS e foi inferido que esses genes podem influenciar as variações sazonais associadas com fatores metabólicos, como peso corporal e apetite ${ }^{25}$.

Nessa perspectiva, este artigo tem por finalidade revisar as pesquisas relacionadas com a regulação molecular do ritmo circadiano e com os transtornos psiquiátricos, a fim de determinar os genes relógio que estão mais associados com esses transtornos, as funções e localizações desses genes, o principal método e modelo utilizados nas pesquisas sobre o tema proposto, o transtorno mais retratado nas análises e as principais limitações e achados dos estudos. É importante destacar que revisões sistemáticas relacionadas a esse tema ainda não estão disponíveis nas bibliotecas PROSPERO e Cochrane.

\section{MÉTODOS}

Por tratar-se de uma revisão sistemática de literatura de natureza descritiva, verificou-se a existência prévia de revisões sistemáticas sobre o tema proposto na Biblioteca Cochrane (The Cochrane Database of Systematic Reviews) (https://www. cochranelibrary.com/) e PROSPERO (International Prospective Register of Systematic Reviews) (www.crd.york.ac.uk/prospero), mas não foram encontradas revisões relacionadas à regulação molecular do ritmo circadiano e sua associação com os transtornos psiquiátricos. Dessa forma, a pesquisa foi cadastrada na PROSPERO (ID 152031).
As diretrizes PRISMA foram seguidas e a busca dos estudos primários foi realizada nas bases de dados PubMed/ MEDLINE (Public MEDLINE) e Scientific Eletronic Library Online (SciELO), por meio de uma estratégia de busca baseada no objeto de estudo. Para a composição da estratégia de busca, utilizaram-se os termos do MeSH - Medical Subject Headings Terms (Tabela 1). Utilizaram-se operadores lógicos de busca (parênteses, trucagem e aspas), além de delimitadores booleanos (AND, OR e NOT). A sintaxe do PubMed serviu de base para a estratégia de pesquisa. A sintaxe consistia em dois temas de pesquisa cruzadas pelo termo booleano "AND". Os termos MESH incluíam termos relacionados a transtornos psiquiátricos ("transtorno bipolar", "transtorno depressivo maior", "transtorno afetivo sazonal", "distúrbios do sono", "comportamento suicida", "ansiedade", "esquizofrenia" e "mudanças sazonais de humor") e termos relacionados aos genes relógio ("ritmo circadiano", "genes circadianos", "genes relógio"). Utilizamos estudos randomizados controlados e excluímos outros tipos de design usando a estratégia de pesquisa altamente sensível (Cochrane e PROSPERO) para identificar ensaios randomizados em MEDLINE, versão maximizadora da sensibilidade. A estratégia não removeu artigos que tratam apenas de animais não humanos. Os termos foram pesquisados em inglês e português e o período da busca foi de janeiro de 2002 a outubro de 2018.

Os critérios de inclusão foram estudos: a) quantitativos ou qualiquantitativos que apresentassem resultados referentes à associação dos transtornos psiquiátricos com a regulação molecular do ritmo circadiano; b) contendo as informações de interesse utilizadas para a elaboração de gráficos e tabelas; c) utilizando modelos humanos e/ou animais; d) disponíveis na língua inglesa ou portuguesa. Foram critérios de exclusão: normas técnicas, manuais, leis, resoluções, editoriais, cartas, comentários, livros, resumo de anais e publicações duplicadas. Em relação a estratégia PICOS, a amostra incluída na presente pesquisa consistiu de indivíduos com transtornos psiquiátricos variados, e a intervenção de interesse foi diagnóstica e por meio de análises genéticas no sangue e tecido. Os indivíduos diagnosticados com transtornos psiquiátricos (grupo experimental) foram comparados

Tabela 1. Estratégias de busca por bases de dados

\begin{tabular}{ll}
\hline Bases de Dados & Estratégia de Busca \\
\hline PubMed & ("psychiatric disorders" [MeSH Terms] OR "depression" \\
& [MeSH Terms] OR "seasonal affective disorder" [MeSH \\
& Terms] OR "sleep disorders" [MeSH Terms]) OR "suicidal \\
& behavior" [MeSH Terms] "anxiety" [MeSH Terms] OR \\
& "Schizophrenia" [MeSH Terms] OR "seasonal mood changes") \\
& AND ("circadian rhythm" [MeSH Terms] OR "circadian genes" \\
& [MeSH Terms] OR "clock genes" [MeSH Terms] ) \\
SciELO & ("transtorno bipolar" OR "transtorno depressivo maior" OR \\
& "transtorno afetivo sazonal" OR "distúrbio do sono" OR \\
& "comportamento suicida" OR "ansiedade" OR "esquizofrenia" \\
& OR "mudanças sazonais de humor") AND ("ritmo circadiano" \\
& OR "genes circadianos" OR "genes relógio") \\
\hline
\end{tabular}


com indivíduos sem esses transtornos (grupo controle) e o resultado esperado consistia na detecção de variações genéticas no grupo experimental. Portanto, neste trabalho incluímos estudos experimentais.

A seleção dos estudos e a extração dos dados foi realizada por três autores de forma independente e iniciou-se por meio da análise dos títulos dos artigos identificados a partir da estratégia de busca. Em seguida, foram realizadas a análise dos resumos e, por fim, a análise do texto na íntegra dos artigos selecionados nas etapas anteriores. As discordâncias entre os autores foram resolvidas por consenso. Diante dessa sistemática, os dados extraídos foram: a) identificação da publicação e base de dados consultada; b) método utilizado na pesquisa; c) transtorno psiquiátrico avaliado; d) gene(s) relacionado(s) ao transtorno e família à qual pertence; e) principal local de expressão do gene no sistema nervoso de humanos; f) funções do gene; g) modelos avaliados na pesquisa; $h$ ) nacionalidade; i) número amostral incluído; j) idade dos indivíduos; k) principais achados do artigo. O local de expressão dos genes analisados e suas funções foram confirmados mediante consulta em banco de dados on-line (https://www.proteinatlas.org/). Para analisar matematicamente as informações acima citadas, em nível de proporção/porcentagem, selecionamos apenas aqueles trabalhos que continham todas essas informações necessárias para as análises.

A ferramenta ROBIS (Risk of Bias in Systematic Reviews) foi utilizada para avaliar risco de viés de revisões sistemáticas. Quase todas as questões foram respondidas como "Sim" ou "Provavelmente Sim", então não foi identificado potencial risco de viés sobre a especificação dos critérios de elegibilidade. A categoria "Sem Informação" foi utilizada apenas quando se dizia a respeito da idade e tamanho amostral da pesquisa. Entretanto, as informações relacionadas com a idade e tamanho amostral dos indivíduos não foram utilizadas para a elaboração dos gráficos. Os estudos "sem informações" associadas a questões utilizadas para a elaboração dos gráficos foram eliminados deste trabalho. Além disso, esforços foram realizados para deixar a pergunta e os objetivos da revisão bem definidos e para justificar que critérios de elegibilidade adequados foram preconizados na revisão. Foi utilizada uma estratégia de busca sensível e apropriada, além de serem tomadas medidas para minimizar o viés e erros na seleção dos estudos, e as características do estudo foram suficientes para que os autores fossem capazes de interpretar os resultados. Por fim, tanto o processo de seleção por títulos e resumos quanto a avaliação dos estudos na íntegra foram selecionados de forma independente por três autores, reduzindo o risco de viés do trabalho.

Os dados extraídos foram confirmados durante uma segunda análise e, após a organização desses dados, as informações relevantes foram apresentadas de forma descritiva por meio de tabelas e, subsequentemente, discutidas no corpo da revisão. As informações de interesse foram compiladas no Excel, o qual forneceu os gráficos e as proporções referentes às variáveis analisadas. Por fim, em relação ao número amostral e à idade dos indivíduos, foi calculada a média dos valores.

\section{RESULTADOS}

O método de busca empregado apontou 5.287 artigos, 2.454 resultaram da pesquisa no banco de dados SciELO e 2.833 foram provenientes do PubMed/MEDLINE. Após a primeira avaliação, 3.279 estudos foram excluídos pela análise dos títulos e resumos, em ambos os casos por não estarem condizentes com a temática e os objetivos desta revisão. Após a leitura na íntegra dos artigos selecionados, 1.923 artigos foram excluídos por não atenderem aos critérios de inclusão ou ainda por atenderem aos critérios de exclusão, mas 61 artigos foram excluídos por estarem duplicados. Ao final, 24 artigos foram incluídos na revisão (Tabelas 2 e 3).

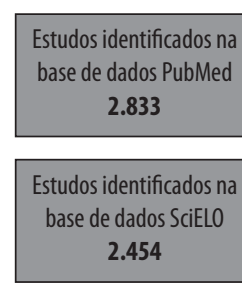

Figura 1. Fluxograma da busca pelos artigos. 
Tabela 2. Pesquisas referentes à influência do ritmo circadiano nos transtornos psiquiátricos

\begin{tabular}{|c|c|c|c|c|}
\hline Referência & $\begin{array}{c}\text { Transtorno } \\
\text { psiquiátrico e } \\
\text { método(s) utilizado(s) }\end{array}$ & $\begin{array}{c}\text { Gene } \\
\text { relógio/família }\end{array}$ & $\begin{array}{c}\text { Principal local de } \\
\text { expressão do gene no } \\
\text { sistema nervoso em } \\
\text { humanos }\end{array}$ & Funções do gene \\
\hline Shiino, $2003^{26}$ & TB (PCR) & $\begin{array}{l}\text { PER2 } \\
\text { Proteína intracelular }\end{array}$ & Núcleo supraquiasmático & $\begin{array}{l}\text { Codifica componentes envolvidos nos ritmos circadianos, na } \\
\text { atividade locomotora, no metabolismo e comportamento. } \\
\text { Polimorfismos nesse gene pode aumentar o risco de contrair } \\
\text { certos tipos de câncer e estão associados a distúrbios do sono. }\end{array}$ \\
\hline Bailer, $2005^{27}$ & TB e TDM unipolar (PCR) & $\begin{array}{l}\text { CLOCK } \\
\text { Enzima }\end{array}$ & Cerebelo & $\begin{array}{l}\text { Codifica proteína com papel central na regulação dos ritmos } \\
\text { circadianos. A proteína contém atividade de acetiltransferase } \\
\text { histona ligante ao DNA. Polimorfismos nesse gene podem estar } \\
\text { associados a mudanças comportamentais em certas populações, } \\
\text { obesidade e síndrome metabólica. }\end{array}$ \\
\hline Artioli, $2007^{18}$ & TDM e TB (PCR) & $\begin{array}{l}\text { PER3 } \\
\text { Proteína intracelular }\end{array}$ & Núcleo supraquiasmático & $\begin{array}{l}\text { Codifica componentes envolvidos nos ritmos circadianos, na } \\
\text { atividade locomotora, no metabolismo e comportamento. } \\
\text { Polimorfismos nesse gene estão associados a síndrome } \\
\text { metabólica, obesidade e alterações comportamentais em certas } \\
\text { populações. }\end{array}$ \\
\hline Kato, $2008^{28}$ & $\begin{array}{l}\text { TB em pacientes com } \\
\text { doença de Wolfram } \\
\text { (Western blot, Microarray } \\
\text { e RT-PCR) }\end{array}$ & $\begin{array}{l}\text { WFS1 } \\
\text { Glicoproteína } \\
\text { transmembrana }\end{array}$ & Gânglios da base & $\begin{array}{l}\text { Codifica uma proteína transportadora de membrana. Mutações } \\
\text { nesse gene estão associadas a síndrome de Wolfram e surdez. }\end{array}$ \\
\hline Kishi, $2008^{29}$ & $\begin{array}{l}\text { TB e TDM } \\
\text { (TaqMan SNP) }\end{array}$ & $\begin{array}{l}\text { NR1D1 } \\
\text { Proteína intracelular }\end{array}$ & Córtex cerebral & $\begin{array}{l}\text { Codifica uma proteína que regula negativamente a expressão dos } \\
\text { genes relógio e que pode estar envolvida em processos } \\
\text { metabólicos, inflamatórios e cardiovasculares. }\end{array}$ \\
\hline Kishi, $2010^{24}$ & TDM (PCR) & $\begin{array}{l}\text { SIRT1 } \\
\text { Proteína intracelular }\end{array}$ & Cerebelo & $\begin{array}{l}\text { As funções da proteína codificada pelo gene ainda são } \\
\text { desconhecidas. Acredita-se que a proteína funcione como } \\
\text { reguladora intracelular em humanos, com uma atividade de } \\
\text { mono-ADP-ribosiltransferase. }\end{array}$ \\
\hline $\begin{array}{l}\text { Dallaspezia, } \\
2011^{30}\end{array}$ & $\begin{array}{l}\text { TDM pós-parto em } \\
\text { portadores de TB (PCR) }\end{array}$ & PER3 $^{*}$ & * & * \\
\hline Wilkosc, $2013^{31}$ & TDM (qPCR) & $\begin{array}{l}\text { ARNTL } \\
\text { Proteína intracelular } \\
\text { TIMELESS } \\
\text { Proteína intracelular, } \\
\text { PER3 e CLOCK* }\end{array}$ & $\begin{array}{l}\text { ARNTL - Córtex cerebral } \\
\text { TIMELESS - Gânglios da } \\
\text { base } \\
\text { CLOCK e PER3* }\end{array}$ & $\begin{array}{l}\text { TIMELESS - A proteína codificada por esse gene está envolvida na } \\
\text { sobrevivência celular após dano ou estresse, aumento na atividade } \\
\text { da DNA polimerase, manutenção do comprimento dos telômeros e } \\
\text { morfogênese das células epiteliais. Alterações no gene estão } \\
\text { envolvidas com alguns tipos de câncer. } \\
\text { ARNTL - A proteína codificada por esse gene forma um } \\
\text { heterodímero com o CLOsCK, o qual se liga aos genes PER e CRY, } \\
\text { ativando suas transcrições. Defeitos nesse gene têm sido } \\
\text { associados a infertilidade, problemas na gliconeogênese, } \\
\text { lipogênese e padrões alterados do sono. } \\
\text { CLOCK e PER3* }\end{array}$ \\
\hline $\begin{array}{l}\text { Szczepankiewicz, } \\
2013^{32}\end{array}$ & TB e TDM (TaqMan SNP) & $\begin{array}{l}\text { CRHR1 } \\
\text { e AVPR1b } \\
\text { Receptores acoplados à } \\
\text { proteína G }\end{array}$ & $\begin{array}{l}\text { CRHR1 - Cerebelo } \\
\text { AVPR1b - Glândula } \\
\text { pituitária }\end{array}$ & $\begin{array}{l}\text { CRHR1 - } 0 \text { receptor codificado por esse gene liga os } \\
\text { neuropeptídeos da família de hormônios liberadores de } \\
\text { corticotropina, que são os principais reguladores da via } \\
\text { hipotálamo-hipófise-adrenal. O receptor é essencial para a } \\
\text { ativação de vias de transdução de sinal que regulam diversos } \\
\text { processos fisiológicos, incluindo estresse, reprodução, resposta } \\
\text { imune e obesidade. } \\
\text { AVPR1b - A proteína codificada por esse gene atua como receptor } \\
\text { da arginina vasopressina. Estimula o sistema mensageiro do } \\
\text { fosfatidil-inositol-cálcio. } 0 \text { receptor também estimula a liberação } \\
\text { de ACTH e é expresso em altos níveis nos adenomas hipofisários } \\
\text { secretores de ACTH. }\end{array}$ \\
\hline Hua, $2014^{33}$ & TDM (PCR) & $\begin{array}{l}\text { CRY1, CRY2, TEF } \\
\text { Proteína intracelular }\end{array}$ & $\begin{array}{l}\text { CRY1 - Cerebelo } \\
\text { CRY2 - Córtex cerebral } \\
\text { TEF - Cerebelo }\end{array}$ & $\begin{array}{l}\text { CRY1/CRY2 - Esse gene codifica uma proteína de ligação ao } \\
\text { dinucleotídeo flavina adenina, que regula o ritmo circadiano. } \\
\text { Polimorfismos nesse gene têm sido associados a padrões } \\
\text { alterados no sono. } \\
\text { TEF - } 0 \text { gene codifica um membro da subfamília PAR (rico em } \\
\text { prolina e aminoácidos). A expressão do TEF coincide com o } \\
\text { aparecimento do hormônio estimulador da tireoide beta (TSHB). De } \\
\text { fato, o TEF pode se ligar e ativar o promotor de TSHB. }\end{array}$ \\
\hline
\end{tabular}
fato, o TEF pode se ligar e ativar o promotor de TSHB. 


\begin{tabular}{|c|c|c|c|c|}
\hline Referência & $\begin{array}{c}\text { Transtorno } \\
\text { psiquiátrico e } \\
\text { método(s) utilizado(s) }\end{array}$ & $\begin{array}{c}\text { Gene } \\
\text { relógio/família }\end{array}$ & $\begin{array}{l}\text { Principal local de } \\
\text { expressão do gene no } \\
\text { sistema nervoso em } \\
\text { humanos }\end{array}$ & Funções do gene \\
\hline Nováková, $2015^{34}$ & $\begin{array}{l}\text { TB associado a } \\
\text { episódios de mania ou } \\
\text { depressão } \\
\text { (RT-qPCR) }\end{array}$ & $\begin{array}{l}\text { PER1 } \\
\text { Proteína intracelular } \\
\text { NR1D1* }\end{array}$ & $\begin{array}{l}\text { PER1 - Córtex cerebral } \\
\text { NR1D1* }\end{array}$ & $\begin{array}{l}\text { PER1 - Codifica componentes envolvidos nos ritmos circadianos, } \\
\text { na atividade locomotora, no metabolismo e comportamento. } \\
\text { Polimorfismos nesse gene podem aumentar o risco de contrair } \\
\text { certos tipos de câncer. } \\
\text { NR1D1* }\end{array}$ \\
\hline $\begin{array}{l}\text { Rybakowski, } \\
2014^{35}\end{array}$ & TB (PCR) & $\begin{array}{l}\text { CLOCK, ARNTL, } \\
\text { TIMELESS, PER3* }\end{array}$ & * & * \\
\hline Maglione, $2015^{36}$ & $\begin{array}{l}\text { TDM } \\
\text { (Golden Gate assay) }\end{array}$ & $\begin{array}{l}\text { RORA } \\
\text { Proteína intracelular, } \\
\text { PER3* }^{*}\end{array}$ & $\begin{array}{l}\text { RORA - Cerebelo } \\
\text { PER3* }^{*}\end{array}$ & $\begin{array}{l}\text { RORA - A proteína codificada por esse gene pode se ligar aos } \\
\text { elementos de resposta hormonal para melhorar a expressão } \\
\text { desses genes. Foi demonstrado que a proteína interage com } \\
\text { NM23-2, um nucleosídeo difosfato cinase, envolvido na } \\
\text { organogênese e diferenciação, bem como com NM23-1, o produto } \\
\text { de um gene candidato a supressor de metástases tumorais. Além } \\
\text { disso, foi demonstrado que a proteína auxilia na regulação } \\
\text { transcricional de alguns genes envolvidos no ritmo circadiano. } \\
\text { PER3* }^{*}\end{array}$ \\
\hline Parekh, $2018^{17}$ & $\begin{array}{l}\text { TB } \\
\text { (Western blot } \\
\text { e RT-PCR) }\end{array}$ & $\begin{array}{l}\text { GLUA1 } \\
\text { Proteína de membrana }\end{array}$ & Hipocampo & $\begin{array}{l}\text { Codifica o principal neurotransmissor excitatório do cérebro, o } \\
\text { glutamato. } 0 \text { glutamato está envolvido no desenvolvimento neural, } \\
\text { na plasticidade sináptica, no aprendizado, na memória, na } \\
\text { epilepsia, na isquemia neural, na tolerância e na dependência a } \\
\text { drogas, na dor neuropática, na ansiedade e na depressão. }\end{array}$ \\
\hline Suzuki, $2017^{37}$ & TB (PCR) & CLOCK $^{*}$ & * & * \\
\hline Banach, $2018^{38}$ & $\begin{array}{l}\text { TB associado a abuso/ } \\
\text { dependência de álcool } \\
\text { (TaqMan SNP) }\end{array}$ & $\begin{array}{l}\text { CLOCK } \\
\text { ARNTL } \\
\text { TIMELESS e PER3* }\end{array}$ & * & * \\
\hline $\begin{array}{l}\text { Matsunaga, } \\
2012^{39}\end{array}$ & $\begin{array}{l}\text { TDM } \\
\text { TB, } \\
\text { Esquizofrenia (PCR) }\end{array}$ & $\begin{array}{l}\text { CSNK1D e CSNK1E } \\
\text { Enzimas }\end{array}$ & $\begin{array}{l}\text { CSNK1D - Córtex } \\
\text { cerebral } \\
\text { CSNK1E - Cerebelo }\end{array}$ & $\begin{array}{l}\text { CSNK1D - A proteína codificada por esse gene está implicada no } \\
\text { controle de processos citoplasmáticos e nucleares, incluindo } \\
\text { replicação e reparo do DNA. A proteína também pode estar } \\
\text { envolvida na regulação da apoptose, ritmo circadiano, dinâmica } \\
\text { dos microtúbulos, segregação cromossômica e efeitos mediados } \\
\text { por p53 no crescimento. } \\
\text { CSNK1E - A proteína codificada por esse gene está implicada no } \\
\text { controle de processos citoplasmáticos e nucleares, incluindo } \\
\text { replicação e reparo do DNA. A proteína é capaz de fosforilar uma } \\
\text { variedade de proteínas, incluindo ela mesma e uma proteína do } \\
\text { ritmo circadiano (PER). }\end{array}$ \\
\hline Kim, $2015^{25}$ & $\begin{array}{l}\text { Transtorno afetivo } \\
\text { sazonal (PCR) }\end{array}$ & $\begin{array}{l}\text { NPAS2 } \\
\text { Proteína intracelular, } \\
\text { CLOCK e ARNTL* }\end{array}$ & $\begin{array}{l}\text { NPAS2 - Gânglios da } \\
\text { base } \\
\text { CLOCK e ARNTL* }\end{array}$ & $\begin{array}{l}\text { NPAS2 - A proteína codificada por esse gene pode desempenhar } \\
\text { um papel regulador na aquisição de tipos de memória específicos, } \\
\text { funcionando também como parte do relógio molecular. }\end{array}$ \\
\hline Węglarz, 20167 & $\begin{array}{l}\text { Distúrbios do sono } \\
\text { (TaqMan SNP) }\end{array}$ & $\begin{array}{l}\text { CLOCK, ARNTL, } \\
\text { TIMELESS e PER3* }\end{array}$ & * & * \\
\hline Pawlak, 2016 $6^{12}$ & $\begin{array}{l}\text { Comportamento suicida } \\
\text { (RT-PCR) }\end{array}$ & $\begin{array}{l}\text { SLC6A4 } \\
\text { Proteína de membrana } \\
\text { HTR2A, HTR2C e } \\
\text { ADRA2A } \\
\text { Receptores acoplados à } \\
\text { proteína G } \\
\text { CRHR1* }^{*}\end{array}$ & $\begin{array}{l}\text { SLC6A4, HTR2A, } \\
\text { ADRA2A - Córtex } \\
\text { cerebral } \\
\text { HTR2C - Gânglios da } \\
\text { base } \\
\text { CRHR1* }\end{array}$ & $\begin{array}{l}\text { SLC6A4 - } 0 \text { gene codifica uma proteína que transporta a } \\
\text { serotonina das fendas sinápticas para os neurônios pré-sinápticos. } \\
\text { A proteína finaliza a ação da serotonina e a recicla. A proteína é } \\
\text { um alvo dos estimulantes psicomotores. Um polimorfismo de } \\
\text { repetição nesse gene afeta a taxa de captação de serotonina, } \\
\text { podendo desempenhar um papel no comportamento agressivo, } \\
\text { doença de Alzheimer, suscetibilidade à depressão e síndrome da } \\
\text { morte súbita do bebê. } \\
\text { HTR2A - } 0 \text { gene codifica um dos receptores da serotonina. } \\
\text { Mutação no HTR2A está associada à suscetibilidade a } \\
\text { esquizofrenia, TOC e resposta ao tratamento antidepressivo. } \\
\text { ADRA2A - O gene codifica um receptor que possui papel crítico } \\
\text { na regulação da liberação de neurotransmissores. } \\
\text { HTR2C - O gene codifica um dos receptores da serotonina. } \\
\text { Anormalidades na edição do RNA desse gene foram associadas à } \\
\text { depressão e ao suicidio. Polimorfismos no promotor desse gene } \\
\text { estão associados com distúrbios comportamentais. } \\
\text { CRHR1* }\end{array}$ \\
\hline
\end{tabular}




\begin{tabular}{|c|c|c|c|c|}
\hline Referência & $\begin{array}{c}\text { Transtorno } \\
\text { psiquiátrico e } \\
\text { método(s) utilizado(s) }\end{array}$ & $\begin{array}{l}\text { Gene } \\
\text { relógio/família }\end{array}$ & $\begin{array}{c}\text { Principal local de } \\
\text { expressão do gene no } \\
\text { sistema nervoso em } \\
\text { humanos }\end{array}$ & Funções do gene \\
\hline \multirow[t]{7}{*}{ Pawlak, $2016^{12}$} & \multirow[t]{7}{*}{$\begin{array}{l}\text { Comportamento suicida } \\
\text { (RT-PCR) }\end{array}$} & \multirow{7}{*}{$\begin{array}{l}\text { TPH1, TPH2, NTRK2 e } \\
\text { ACP1 } \\
\text { Enzimas } \\
\text { BDNF } \\
\text { Proteína intracelular }\end{array}$} & \multirow{7}{*}{$\begin{array}{l}\text { TPH2, BDNF - Ponte e } \\
\text { medula } \\
\text { TPH1 e ACP1 - Córtex } \\
\text { cerebral } \\
\text { NTRK2 -Amígdala }\end{array}$} & $\begin{array}{l}\text { TPH2 - Esse gene codifica uma proteína que catalisa o primeiro } \\
\text { passo na biossíntese da serotonina. Mutações nesse gene estão }\end{array}$ \\
\hline & & & & associadas ao TB e TDM. \\
\hline & & & & BDNF - Esse gene codifica uma proteína envolvida no crescimento \\
\hline & & & & $\begin{array}{l}\text { e sobrevivência neuronal. A expressão desse gene é reduzida nas } \\
\text { doenças de Alzheimer, Parkinson e Huntington. Esse gene pode } \\
\text { desempenhar um papel nos transtornos de humor e resposta ao } \\
\text { estresse. }\end{array}$ \\
\hline & & & & $\begin{array}{l}\text { TPH1 - Esse gene codifica uma proteína que catalisa o primeiro } \\
\text { passo na biossíntese da serotonina. Mutações nesse gene estão } \\
\text { associadas a esquizofrenia, ansiedade, TB, comportamento } \\
\text { suicida, vícios e outros. }\end{array}$ \\
\hline & & & & $\begin{array}{l}\text { ACP1 - } 0 \text { produto desse gene funciona como uma fosfatase ácida } \\
\text { e uma tirosina fosfatase. Esta enzima também hidrolisa } \\
\text { monoésteres ortofosfóricos. }\end{array}$ \\
\hline & & & & $\begin{array}{l}\text { NTRK2 - Esse gene codifica um receptor que, após a ligação à } \\
\text { neurotrofina, fosforila a si próprio e aos membros da família MAPK. } \\
\text { A sinalização por meio dessa cinase leva à diferenciação celular e } \\
\text { mutações nesse gene têm sido associadas a obesidade e } \\
\text { transtornos de humor. }\end{array}$ \\
\hline Pawlak, $2017^{40}$ & $\begin{array}{l}\text { TB e comportamento } \\
\text { suicida (RT-PCR) }\end{array}$ & $\begin{array}{l}\text { CLOCK, ARNTL, } \\
\text { TIMELESS e PER3* }\end{array}$ & * & * \\
\hline \multirow[t]{2}{*}{ Yang, $2018^{41}$} & \multirow[t]{2}{*}{$\begin{array}{l}\text { Mudanças sazonais de } \\
\text { humor (RT-PCR) }\end{array}$} & \multirow[t]{2}{*}{$\begin{array}{l}\text { ST8SIA2 e NCAM1 } \\
\text { Proteína intracelular }\end{array}$} & \multirow[t]{2}{*}{$\begin{array}{l}\text { ST8SIA2 - Ponte e } \\
\text { medula } \\
\text { NCAM1 - } \\
\text { Mesencéfalo }\end{array}$} & $\begin{array}{l}\text { ST8SIA2 - A proteína codificada por esse gene pode estar } \\
\text { envolvida com a catálise da transferência de ácido siálico aos } \\
\text { oligossacarídeos e glicoproteínas. A proteína pode estar envolvida } \\
\text { com a produção de ácido polissiálico, um modulador das } \\
\text { propriedades adesivas da molécula de adesão a células neuronais } \\
\text { (NCAM1). }\end{array}$ \\
\hline & & & & $\begin{array}{l}\text { NCAM1 - Esse gene codifica uma proteína de adesão celular, que } \\
\text { está envolvida nas interações célula-célula e nas interações } \\
\text { célula-matriz durante o desenvolvimento e diferenciação. A } \\
\text { proteína está envolvida no desenvolvimento do sistema nervoso e } \\
\text { das células envolvidas com a expansão das células T, } \\
\text { desempenhando um papel importante no sistema imune. }\end{array}$ \\
\hline Zhang, $2017^{8}$ & $\begin{array}{l}\text { Comportamento } \\
\text { depressivo (RT-qPCR) }\end{array}$ & $\begin{array}{l}\text { ARNTL, CLOCK, PER1 e } \\
\text { PER2* }\end{array}$ & * & * \\
\hline Zhao, $2018^{9}$ & Ansiedade (qPCR) & $\begin{array}{l}\text { GFP - Enzima } \\
\text { NR1D1* }^{*}\end{array}$ & $\begin{array}{l}\text { GFP - Córtex cerebral } \\
\text { NR1D1* }\end{array}$ & $\begin{array}{l}\text { GFP - Codifica a enzima que limita a taxa da via da hexosamina e } \\
\text { controla o fluxo de glicose nessa via. } 0 \text { produto desse gene } \\
\text { também catalisa a formação de glucosamina-6-fosfato. } \\
\text { NR1D1* }^{*}\end{array}$ \\
\hline Liberman, $2018^{42}$ & $\begin{array}{l}\text { Depressão e ansiedade } \\
\text { (RT-qPCR) }\end{array}$ & $\begin{array}{l}\text { REV Proteína intracelular } \\
\text { PER1/2/3, CRY1/2, } \\
\text { ARNTL, CLOCK, NPAS2* }\end{array}$ & $\begin{array}{l}\text { REV - Cerebelo } \\
\text { PER1, PER2, PER3, } \\
\text { CRY1/2, ARNTL, CLOCK, } \\
\text { NPAS2* }\end{array}$ & $\begin{array}{l}\text { REV - As proteínas REV contêm um domínio importante nas } \\
\text { interações proteína-proteína. Um papel sugerido da proteína é } \\
\text { recrutar polimerases de DNA envolvidas na síntese do DNA } \\
\text { danificado. }\end{array}$ \\
\hline & & & & PER1, PER2, PER3, CRY1/2, ARNTL CLOCK, NPAS2* \\
\hline
\end{tabular}

Legenda: Os asteriscos representam informações já citadas anteriormente na tabela. PCR: reação de cadeia da polimerase; q-PCR: reação de cadeia da polimerase quantitativa; RT-PCR: reação de cadeia da polimerase em tempo real; TB: transtorno bipolar; TDM: transtorno depressivo maior; BDI-HDRS: Inventário de Depressão de Beck, avaliado pela Escala de Depressão de Hamilton.

Tabela 3. Pesquisas referentes à influência do ritmo circadiano nos transtornos psiquiátricos

\begin{tabular}{|c|c|c|c|c|c|}
\hline Referência & Modelo & n & Idade & Principais achados & Limitações dos e \\
\hline Shiino, $2003^{26}$ & $\begin{array}{c}\text { Humanos } \\
\text { (Japão) }\end{array}$ & 215 & $43,3+/-14,1$ & $\begin{array}{l}\text { Não houve diferença significativa entre os pacientes } \\
\text { com TB e controles em relação à frequência do } \\
\text { polimorfismo S662G. }\end{array}$ & $\begin{array}{l}\text { No presente estudo foi analis } \\
\text { parte do gene } P E R 2 \text {. Outros } \\
\text { restantes na região de ligaçã } \\
\text { foram investigados. }\end{array}$ \\
\hline Bailer, $2005^{27}$ & $\begin{array}{l}\text { Humanos } \\
\text { (Áustria) }\end{array}$ & 205 & $44,06+/-14,28$ & $\begin{array}{l}\text { Não foi encontrada associação entre o SNP T3111C do } \\
\text { gene CLOCKe o transtorno afetivo. Testes adicionais } \\
\text { referentes ao SNP T3111C e idade de início, número } \\
\text { de episódios afetivos e subtipo melancólico também } \\
\text { não mostraram associações significativas. }\end{array}$ & Pequeno tamanho amostral. \\
\hline
\end{tabular}




\begin{tabular}{|c|c|c|c|c|c|}
\hline Referência & Modelo & $\mathbf{n}$ & Idade & Principais achados & Limitações dos estudos \\
\hline Artioli, $2007^{18}$ & $\begin{array}{l}\text { Humanos } \\
\text { (Itália) }\end{array}$ & 1.031 & $49,91+/-13,42$ & $\begin{array}{l}\text { Os genótipos PER3 podem influenciar características } \\
\text { específicas em indivíduos com transtorno de humor. }\end{array}$ & $\begin{array}{l}\text { Fraqueza das associações observadas e } \\
\text { frequentes achados falso-positivos. }\end{array}$ \\
\hline Kato, $2008^{28}$ & $\begin{array}{l}\text { Camundongos } \\
\text { C57BL/6J (B6) } \\
\text { knockout para } \\
\text { Wfs1 }\end{array}$ & 20 & 34 semanas & $\begin{array}{l}\text { Camundongos knockout WFS1 apresentaram retardo } \\
\text { no comportamento e diminuição da interação social. } \\
\text { A imunorreatividade do tipo WFS1 no cérebro de } \\
\text { camundongos mostrou um padrão de distribuição } \\
\text { com vários núcleos potencialmente relevantes para } \\
\text { os sintomas dos transtornos do humor. }\end{array}$ & $\begin{array}{l}\text { Função do WFS1 ainda não bem estabelecida } \\
\text { na literatura. }\end{array}$ \\
\hline Kishi, $2008^{29}$ & $\begin{array}{l}\text { Humanos } \\
\text { (Japão) }\end{array}$ & 829 & $44,8+/-15$ & $\begin{array}{l}\text { Nenhuma associação significativa foi encontrada } \\
\text { com TDM. Os achados sugerem que a NR1D1 não } \\
\text { desempenha um papel importante na fisiopatologia } \\
\text { dos transtornos de humor na população japonesa. }\end{array}$ & $\begin{array}{l}\text { A falta de associação pode ser devida a } \\
\text { amostras enviesadas, como amostras } \\
\text { envelhecidas sem correspondência, ou } \\
\text { pequeno tamanho amostral. }\end{array}$ \\
\hline Kishi, $2010^{24}$ & $\begin{array}{l}\text { Humanos } \\
\text { (Japão) }\end{array}$ & 1.216 & $43,2+/-17,3$ & $\begin{array}{l}\text { Associação significativa entre o haplótipo } \\
\text { rs10997875 do gene SIRT1 e pacientes japoneses } \\
\text { com TDM. Não houve relação significativa entre o } \\
\text { gene SIRT1 e a responsividade ao tratamento com o } \\
\text { inibidor seletivo da recaptação da serotonina (SSRI). }\end{array}$ & $\begin{array}{l}\text { Ausência de triagem de mutações, pequeno } \\
\text { tamanho amostral, diferença de idade } \\
\text { significativa entre os grupos. }\end{array}$ \\
\hline $\begin{array}{l}\text { Dallaspezia, } \\
2011^{30}\end{array}$ & $\begin{array}{l}\text { Humanos } \\
\text { (Itália) }\end{array}$ & 67 & $27,11+/-6,44$ & $\begin{array}{l}\text { Homozigotos PER3 portadores de TB possuem risco } \\
\text { aumentado de depressão no pós-parto. } 0 \text { alelo PER3 } \\
5 \text { protege contra o início de depressão pós-parto em } \\
\text { portadores de TB, mas aumenta o risco de câncer de } \\
\text { mama na pré-menopausa. }\end{array}$ & $\begin{array}{l}\text { Pequeno tamanho amostral, ausência de uma } \\
\text { melhor descrição dos critérios de escolha, } \\
\text { falta de utilização de testes comportamentais } \\
\text { e análise de outros polimorfismos. }\end{array}$ \\
\hline Wilkosc, $2013^{31}$ & $\begin{array}{c}\text { Humanos } \\
\text { (Polônia) }\end{array}$ & 1.475 & - & $\begin{array}{l}\text { Foi sugerido um papel putativo dos polimorfismos } \\
\text { CLOCK, ARNTL e TIMELESS na suscetibilidade a } \\
\text { transtornos do humor. }\end{array}$ & $\begin{array}{l}\text { Amostragem pouco caracterizada, pequeno } \\
\text { tamanho amostral, Metodologia e resultados } \\
\text { pouco descrita e discutidos, respectivamente. }\end{array}$ \\
\hline $\begin{array}{l}\text { Szczepankiewicz, } \\
2013^{32}\end{array}$ & $\begin{array}{c}\text { Humanos } \\
\text { (Polônia) }\end{array}$ & 1.413 & $43,3+/-13,3$ & $\begin{array}{l}\text { A análise da interação gene-gene revelou uma } \\
\text { interação epistática significativa entre os genes } \\
\text { AVPR1b e CRHR1 na suscetibilidade ao TDM. } \\
\text { Polimorfismos de CRHR1 e AVPR1b podem modificar } \\
\text { a suscetibilidade a transtornos de humor. }\end{array}$ & $\begin{array}{l}\text { Ausência de triagem psiquiátrica cautelosa } \\
\text { no grupo controle, resultando em falso- } \\
\text { negativos ou falso-positivos. Pequeno } \\
\text { tamanho amostral. }\end{array}$ \\
\hline Hua, $2014^{33}$ & $\begin{array}{l}\text { Humanos } \\
\text { (China) }\end{array}$ & 590 & $65,2+/-6,55$ & $\begin{array}{l}\text { Relação significativa dos SNP rs2287161 de CRY1 e } \\
\text { rs738499 de TEF com TDM. Não houve relação } \\
\text { significativa entre o SNP de CRY2 e TDM. }\end{array}$ & $\begin{array}{l}\text { Pequeno tamanho amostral do grupo com } \\
\text { TDM. }\end{array}$ \\
\hline Nováková, $2015^{34}$ & $\begin{array}{l}\text { Humanos } \\
\text { (República } \\
\text { Tcheca) }\end{array}$ & 57 & $41,8+/-3,13$ & $\begin{array}{l}\text { Os dados revelaram diferenças no estado funcional } \\
\text { do ciclo circadiano em pacientes com TB, } \\
\text { dependendo se eles estavam experimentando um } \\
\text { episódio maníaco ou depressivo. }\end{array}$ & $\begin{array}{l}\text { Pacientes com TB eram medicados durante } \\
\text { todo o estudo. } 0 \text { papel do lítio no TB precisa } \\
\text { ser considerado, porque o lítio afeta } 0 \\
\text { mecanismo do gene relógio por meio de } \\
\text { múltiplas vias. }\end{array}$ \\
\hline $\begin{array}{l}\text { Rybakowski, } \\
2014^{35}\end{array}$ & $\begin{array}{l}\text { Humanos } \\
\text { (Polônia) }\end{array}$ & 70 & $59+/-12$ & $\begin{array}{l}\text { Foram encontradas associações entre } \\
\text { temperamentos hipertímico e ansioso com SNPs do } \\
\text { gene } A R N T L \text {. } \\
\text { Foram encontradas associações entre } \\
\text { temperamentos ciclotímico e depressivo com SNPs } \\
\text { dos genes TIM e PER3. } \\
\text { Nenhuma associação foi observada com SNPs do } \\
\text { gene CLOCK. }\end{array}$ & $\begin{array}{l}\text { Pequeno tamanho amostral e correção } \\
\text { insuficiente para múltiplos testes. }\end{array}$ \\
\hline Maglione, $2015^{36}$ & $\begin{array}{l}\text { Humanos } \\
\text { (Estados } \\
\text { Unidos) }\end{array}$ & 2.010 & $80,3+/-4,57$ & $\begin{array}{l}\text { Significativa relação entre PER3 e alguns sintomas } \\
\text { do TDM e significativa relação entre RORA e muitos } \\
\text { sintomas do TDM. }\end{array}$ & $\begin{array}{l}\text { Pequeno tamanho amostral e uso de um } \\
\text { questionário em vez de uma entrevista } \\
\text { diagnóstica para avaliar sintomas } \\
\text { depressivos. }\end{array}$ \\
\hline Parekh, $2018^{17}$ & $\begin{array}{l}\text { Camundongos } \\
\text { BALB/cJ } \\
\text { mutantes } \\
\text { para Clock } \triangle 19\end{array}$ & - & 6-12 semanas & $\begin{array}{l}\text { A sinalização excitatória do nucleus accumbens via } \\
\text { expressão de Gria1 é essencial para os efeitos do } \\
\text { gene CLOCK em comportamentos tipo maníacos. }\end{array}$ & $\begin{array}{l}\text { Incapacidade de determinar a identidade } \\
\text { celular de neurônios em mutantes do gene } \\
\text { CLOCK. }\end{array}$ \\
\hline Suzuki, $2017^{37}$ & $\begin{array}{l}\text { Humanos } \\
\text { (Itália) }\end{array}$ & 132 & $47,75+/-11,5$ & $\begin{array}{l}\text { Os portadores do polimorfismo rs1801260 do gene } \\
\text { CLOCK apresentaram maiores escores de } \\
\text { discrepância no BDI-HDRS do que os homozigotos. A } \\
\text { análise de mediação revelou que a dimensão da } \\
\text { cognição depressiva medeia completamente a } \\
\text { associação entre o polimorfismo do CLOCKe a } \\
\text { discrepância entre BDI-HDRS. }\end{array}$ & $\begin{array}{l}\text { Muitos polimorfismos genéticos diferentes do } \\
\text { gene CLOCK também podem influenciar a } \\
\text { discrepância do BDI-HDRS e as distorções } \\
\text { cognitivas depressivas. }\end{array}$ \\
\hline
\end{tabular}




\begin{tabular}{|c|c|c|c|c|c|}
\hline Referência & Modelo & n & Idade & Principais achados & Limitações dos estudos \\
\hline Banach, $2018^{38}$ & $\begin{array}{c}\text { Humanos } \\
\text { (Polônia) }\end{array}$ & 853 & $45,5+/-10,75$ & $\begin{array}{l}\text { Confirmação da existência de ligações diretas entre } \\
\text { os genes relógio, doenças comórbidas e } \\
\text { predisposição genética para abuso/dependência de } \\
\text { álcool. Os homens apresentam mais frequentemente } \\
\text { um cronotipo noturno e isso predispõe aos vícios. }\end{array}$ & $\begin{array}{l}\text { Pequeno tamanho amostral, falta de dados } \\
\text { de verificação e de entrevista com o paciente. } \\
\text { Além da desproporção de gênero. }\end{array}$ \\
\hline $\begin{array}{l}\text { Matsunaga, } \\
2012^{39}\end{array}$ & $\begin{array}{l}\text { Humanos } \\
\text { (Japão) }\end{array}$ & 8.115 & $47,5+/-15$ & $\begin{array}{l}\text { A correlação entre SNPs dos genes estudados com } \\
\text { TB, depressão e esquizofrenia não foi significativa. }\end{array}$ & $\begin{array}{l}\text { Não foram avaliadas interações gene-gene. } \\
\text { Amostras coletadas em diversas regiões do } \\
\text { Japão, podendo resultar em heterogeneidade } \\
\text { genética. }\end{array}$ \\
\hline Kim, $2015^{25}$ & $\begin{array}{l}\text { Humanos } \\
\text { (Coreia do Sul) }\end{array}$ & 507 & - & $\begin{array}{l}\text { Primeiro estudo a revelar associações entre o gene } \\
C L O C K \text {, variações sazonais de humor e } \\
\text { comportamentos em uma população coreana. }\end{array}$ & Não foram apontadas limitações do estudo. \\
\hline Węglarz, $2016^{7}$ & $\begin{array}{l}\text { Humanos } \\
\text { (Polônia) }\end{array}$ & 237 & $40,5+/-9,5$ & $\begin{array}{l}\text { Os resultados obtidos confirmam o papel do SNP } \\
\text { rs } 11600996 \text { do gene relógio ARNTL em distúrbios da } \\
\text { qualidade do sono. } 0 \text { estudo também mostra } \\
\text { interações epistáticas significativas entre } 0 \\
\text { polimorfismo do gene PER3 (rs2640909) e do gene } \\
\text { CLOCK (rs11932595) e a duração do sono, eficiência } \\
\text { habitual do sono e qualidade subjetiva do sono. }\end{array}$ & $\begin{array}{l}\text { Pequeno tamanho da amostra, baixo número } \\
\text { de polimorfismos selecionados, estudos de } \\
\text { associação não foram possíveis e a ausência } \\
\text { do uso de métodos objetivos para avaliar a } \\
\text { qualidade do sono. }\end{array}$ \\
\hline Pawlak, $2016^{12}$ & $\begin{array}{c}\text { Humanos } \\
\text { (Polônia) }\end{array}$ & 1.672 & $37,3+/-12,5$ & $\begin{array}{l}\text { Confirmou o papel dos polimorfismos de TPH1, } \\
\text { TPH2, 5HT2A, CRHR1 e ACP1 no risco de } \\
\text { comportamento suicida. }\end{array}$ & $\begin{array}{l}\text { Número limitado de genes candidatos. } \\
\text { Ausência de dados sobre o tratamento } \\
\text { farmacológico dos pacientes investigados. }\end{array}$ \\
\hline Pawlak, $2017^{40}$ & $\begin{array}{c}\text { Humanos } \\
\text { (Polônia) }\end{array}$ & 577 & - & $\begin{array}{l}\text { Significativa relação entre variantes genéticas } \\
\text { selecionadas entre CLOCK, ARNTL, TIMELESS e } \\
\text { PER3 e variáveis que descrevem o curso da doença; } \\
\text { falta de correlação epistática significativa entre } \\
\text { variantes genéticas circadianas e número de } \\
\text { tentativas de suicídio. }\end{array}$ & $\begin{array}{l}\text { Lista de fatores de risco suicida não é } \\
\text { específico para TB. Fatores de risco de } \\
\text { abordagem psicológica, número de } \\
\text { participantes, dados clínicos e genéticos } \\
\text { limitados. }\end{array}$ \\
\hline Yang, $2018^{41}$ & $\begin{array}{l}\text { Humanos } \\
\text { (Coreia do Sul) }\end{array}$ & 261 & - & $\begin{array}{l}\text { Demonstrou associações entre variantes de ST8SIA2 } \\
\text { e NCAM1 com sazonalidade em indivíduos saudáveis } \\
\text { da população geral coreana. } \\
\text { Sugere que esses dois genes podem ter um papel } \\
\text { importante na preferência da regulação do ciclo } \\
\text { circadiano. }\end{array}$ & $\begin{array}{l}\text { Análise incompleta da região genômica do } \\
\text { NCAM1. Apenas indivíduos saudáveis foram } \\
\text { analisados neste estudo. }\end{array}$ \\
\hline Zhang, $2017^{8}$ & $\begin{array}{l}\text { Camundongos } \\
\text { C57BL/6J }\end{array}$ & 309 & $6-8$ semanas & $\begin{array}{l}\text { A exposição materna a distúrbios circadianos } \\
\text { crônicos durante a gravidez pode levar a transtornos } \\
\text { de humor que persistem por pelo menos duas } \\
\text { gerações filiais. Os mecanismos subjacentes podem } \\
\text { depender de alterações nos níveis plasmáticos de } \\
\text { corticosterona, marca-passo circadiano e expressão } \\
\text { da proteína hipotalâmica. }\end{array}$ & $\begin{array}{l}\text { Resta determinar se os machos que sofreram } \\
\text { mecanismos estressores no útero têm } \\
\text { descendentes com suscetibilidade ao } \\
\text { desenvolvimento de transtornos psiquiátricos. }\end{array}$ \\
\hline Zhao, $2018^{9}$ & $\begin{array}{l}\text { Camundongos } \\
\text { C57BL/6J }\end{array}$ & 54 & 10-12 semanas & $\begin{array}{l}\text { NR1D1 modula o comportamento relacionado com a } \\
\text { sociabilidade e ansiedade de uma maneira } \\
\text { específica. } 0 \text { ritmo circadiano pode estar envolvido } \\
\text { na expressão desses fenótipos comportamentais. }\end{array}$ & Não foram apontadas limitações do estudo. \\
\hline Liberman, $2018^{42}$ & $\begin{array}{l}\text { Humanos } \\
\text { (Estados } \\
\text { Unidos) }\end{array}$ & 528 & $19+/-1$ & $\begin{array}{l}0 \text { polimorfismo rs57875989 do gene PER3 foi } \\
\text { significativamente associado à depressão, e } \\
\text { indivíduos homozigotos para SNP rs228697 do gene } \\
\text { PER3, relataram maior ansiedade. }\end{array}$ & $\begin{array}{l}\text { Não foi avaliado o papel do sono no estudo. } \\
\text { Uso de questionários para medir a depressão } \\
\text { e ansiedade, ao invés de uma entrevista } \\
\text { diagnóstica. Abordagem de genes candidatos } \\
\text { altamente seletiva. }\end{array}$ \\
\hline
\end{tabular}

\section{O gene PER, o transtorno bipolar e o transtorno depressivo maior}

Pesquisas relacionadas à participação do ritmo circadiano em transtornos psiquiátricos são recentes, assim, é válido considerar a importância dos resultados encontrados nesses estudos envolvendo tanto humanos quanto animais. $O$ primeiro estudo examinou a frequência do polimorfismo S662G do gene PER2 em pacientes com TB e controles normais.
Embora os resultados mostrem que o polimorfismo do gene PER2 não está associado à etiologia do TB, o polimorfismo pode estar associado a outros distúrbios relacionados ao ritmo circadiano, tal como a insônia ${ }^{26}$. Outro estudo, por sua vez, mostrou uma associação entre o TDM e um haplótipo específico composto pelos éxons 15 e 18 do gene PER3. Além disso, variantes genéticas raras de PER3 estão significativamente associadas a uma série de características dos 
transtornos psiquiátricos, tais como idade de início, resposta ao tratamento, oscilações do humor circadiano e características de temperamento ${ }^{18}$.

Dallaspezia et al., por sua vez, investigaram os efeitos das variantes de PER3 no desenvolvimento do TDM em portadores de TB no pós-parto ${ }^{30}$. Foi realizada uma PCR com primers específicos para o polimorfismo de repetição em tandem de número variável (VNTR) do gene PER3. Esse VNTR demonstrou influenciar o padrão de secreção de citocinas, gerando um desequilíbrio nas citocinas anti-inflamatórias, que tem sido associado a um aumento no risco de depressão pós-parto. Adicionalmente, homozigotos PER3 4/4 possuíram risco aumentado de depressão no pós-parto, e o alelo PER3 5 protegeu contra o início dessa condição em portadores de TB, mas aumentou o risco de câncer de mama na pré-menopausa ${ }^{30}$. Além de Dallaspezia et al. e outros autores, Wilkosc et al. também avaliaram associações do gene PER3 com os transtornos de humor, em especial o TDM ${ }^{31}$. Neste trabalho foi realizada uma reação em cadeia da polimerase quantitativa em tempo real (qPCR) com primers para nove polimorfismos do PER3, embora não tenham sido descritos quais polimorfismos foram analisados. Entretanto, não foi encontrada nenhuma relação entre os polimorfismos do PER3 e algum transtorno psiquiátrico nessa população ${ }^{31}$.

Em um outro estudo, foi verificado que as alterações estudadas do gene PER3 são, na realidade, mutações de ganho de função, ocasionando um aumento na taxa de transcrição (previsões que devem ser verificadas experimentalmente em estudos futuros). Foi elaborado um simples modelo matemático capaz de simular essas mutações e seus efeitos no desalinhamento circadiano ${ }^{42}$. Maglione et al. também analisaram o gene PER3 e, em resumo, sugerem que os genes PER3 e RORA podem desempenhar papéis importantes na fisiopatologia da depressão em idosos ${ }^{36}$. Entretanto, alguns estudos, como os realizados por Shiino, Kishi, Matsunaga e Hua, não encontraram associações significativas dos genes PER2, SIRT1, CSNK1D, CSNK1E e CRY2 com os marcadores de transtornos psiquiátricos, permitindo uma discussão mais abrangente a respeito de outros polimorfismos e genes relógio $24,26,33,39$.

\section{O gene TIMELESS e o transtorno bipolar}

Em 2017, Pawlak et al. realizaram uma análise da relação entre os genes relógio e o desenvolvimento do TB. Nesse estudo, foram encontradas associações entre os polimorfismos dos genes TIMELESS e PER3 e o número de episódios depressivos. O número médio de episódios depressivos por ano de doença, por sua vez, esteve relacionado com polimorfismos dos genes TIMELESS e ARNTL. Já a proporção de episódios depressivos e a história familiar de tentativa(s) suicida(s) também estiveram relacionadas com o gene TIMELESS ${ }^{40}$. Em outro trabalho, procedeu-se a uma análise investigativa compreendendo a associação entre múltiplos polimorfismos de nucleotídeo único (SNPS) dos genes relógio TIMELESS, CLOCK, ARNTL, PER3 e dimensões temperamentais do TEMPS-A, em pacientes diagnosticados com TB. O estudo indicou que os genes ARNTL, TIMELESS e PER3 podem estar associados a comportamentos mediados pelo TEMPS-A, enfatizando que os SNPs desses genes podem ainda estar relacionados com a predisposição ao $\mathrm{TB}^{35}$.

\section{O gene WFS1 e o transtorno bipolar}

Foi observada uma relação entre a doença de Wolfram e o $\mathrm{TB}^{34}$. Em 2008, Kato et al. realizaram um estudo com animais knockout para o gene WFS1 e observaram que esses animais não apresentaram problemas de saúde que são observados em pacientes com a doença de Wolfram. Os resultados mostraram que os camundongos WFS1 knockout possuíram alterações em suas características comportamentais, como diminuição da interação social, o que é relevante para os fenótipos neuropsiquiátricos relatados em pacientes com doença de Wolfram. Adicionalmente, pacientes com TB apresentaram diferenças nos sistemas circadianos, dependendo se o indivíduo estava vivenciando um episódio de mania ou depressão. Os resultados inferiram que o gene relógio WFS1 pode estar envolvido em tais transtornos ${ }^{34}$.

\section{O gene NR1D1, ansiedade e depressão}

Posteriormente, Zhao e Gammie mostraram que a inibição do gene circadiano NR1D1 pode melhorar a sociabilidade e reduzir a ansiedade 9 . As descobertas são consistentes com trabalhos anteriores, que identificaram diminuições naturais na expressão de NR1D1, o que esteve associado ao surgimento de comportamentos pró-sociais. O papel regulador do fator de transcrição NR1D1 é provavelmente alcançado ao desencadear ações no sistema circadiano. Futuros estudos podem avaliar as maneiras complexas pelas quais o NR1D1 contribuiu para mudanças no comportamento social ${ }^{9}$. O estudo de Kishi mostrou a associação entre um SNP do gene NR1D1 e o TB em mulheres. No entanto, se não houve uma associação após o teste estatístico de Bonferroni, não podemos considerar que houve inicialmente uma associação. Além disso, nenhuma associação significativa foi encontrada para o TDM, sugerindo que o gene NR1D1 provavelmente não desempenha um papel importante nos transtornos psiquiátricos na população japonesa ${ }^{29}$.

\section{O gene CLOCK e o transtorno afetivo sazonal}

Parekh et al. utilizaram a eletrofisiologia em células ex vivo de camundongos mutantes para o gene CLOCKA19 e camundongos selvagens. Nesse sentido, as alterações na transmissão sináptica excitatória e a força e excitabilidade intrínseca dos neurônios do nucleus accumbens (NAc) foram caracterizadas. Os autores procederam com a análise Western blot para examinar os níveis superficiais e intracelulares de proteínas, entre as quais estavam o receptor de glutamato, GLUA1, 
no NAc. A superexpressão de GRIA1 também foi estudada, mostrando-se essencial para os efeitos do gene CLOCK em comportamentos tipo maníacos ${ }^{17}$. Kim et al. avaliaram a relação dos genes CLOCK, ARNTL e NPAS2 em adultos saudáveis com as variações de sazonalidade (SAD) e mostraram que a prevalência de SAD foi de 12,0\% (no inverno 9,3\%, e no verão 2,8\%). Nenhuma diferença significativa foi encontrada entre os grupos na distribuição genotípica do ARNTL rs2278749 e do NPAS2 rs2305160. Entretanto, foram observadas diferenças estatísticas nas subescalas peso corporal e apetite entre os genótipos do ARNTL rs2278749 e na subescala peso corporal entre os genótipos do NPAS2 rs2305160. Além disso, houve interação sinérgica entre CLOCK rs1801260 e ARNTL rs2278749 na sazonalidade ${ }^{25}$. Por fim, Bailer et al. investigaram se, em pacientes com depressão unipolar e TB, o SNP T3111C do gene CLOCK está associado com transtornos afetivos em comparação com os controles saudáveis. Nesse sentido, não foram encontradas diferenças nas distribuições de frequências do genótipo ou alelo do polimorfismo T3111C entre os pacientes. Assim sendo, os resultados sugerem que não há associação entre o SNP T3111C do gene CLOCK e os transtornos afetivos em geral ${ }^{27}$.

\section{Outros genes relacionados ao transtorno depressivo maior e ao comportamento suicida}

Kishi et al., em 2010, indicaram uma associação entre o polimorfismo rs10997875 do gene SIRT1 e o TDM, porém não foram registradas associações entre o gene analisado e a resposta terapêutica ao inibidor seletivo da recaptação da serotonina na fisiopatologia do TDM ${ }^{24}$. Adicionalmente, Matsunaga et al. realizaram uma metanálise para relacionar quatro SNPs do gene CSNK1D e sete SNPs do gene CSNK1E com o TDM, TB e esquizofrenia. Nesse contexto, foi utilizado um banco de dados de polimorfismos da população japonesa, no entanto não foram encontradas relações significativas entre os polimorfismos dos genes CSNK1D e CSNK1E com o TDM, TB e esquizofrenia ${ }^{39}$. Szczepankiewicz et al., por sua vez, tinham o objetivo de detectar uma possível associação das variantes dos genes CRHR1 e AVPR1b com o TB e TDM. A análise da interação gene-gene conseguiu revelar uma interação epistática significativa entre os genes e a suscetibilidade ao TDM ${ }^{32}$. Os genes CRY1 e TEF também foram investigados quanto às suas relações com a depressão. Hua et al. visaram replicar e analisar a associação entre variantes de genes relógio e o TDM, relatando que as variantes rs2287161 de CRY1 e rs738499 de TEF estão associadas à suscetibilidade ao TDM ${ }^{33}$.

Pawlak et al. conduziram a análise de polimorfismos de genes que possuíam uma relação já estabelecida com a vulnerabilidade ao suicídio. Nesse sentido, foram selecionados 10 genes e 35 SNPs e foi utilizado o sangue de pacientes com transtornos de comportamento. A amplificação dos genes foi feita por meio de PCR em tempo real e o teste de genotipagem de polimorfismos nucleotídicos (TaqMan
SNP) também foi realizado em 10\% das amostras escolhidas aleatoriamente de ambos os grupos para verificar a precisão da genotipagem. Uma ampla análise de 34 SNPs da região ST8SIA2 e 15 SNPs de NCAM1 foi desenvolvida. Os resultados demonstraram uma evidência significativa e/ou sugestiva da associação entre fenótipos comportamentais que refletem o ritmo biológico humano e genes envolvidos na plasticidade da rede neuronal do sistema nervoso central. A fisiopatologia do TB ou depressivo possui características cronobiológicas importantes, de forma que a sazonalidade e a preferência circadiana são fenótipos que estão inter-relacionados ${ }^{41}$.

Por fim, Zhang et al. revelaram que o estresse pré-natal pode levar a comportamentos semelhantes a depressão nas gerações F1 e F2. Esses comportamentos em camundongos F1 estão associados a perturbações na expressão de genes relógio no sistema nervoso central e à alteração da expressão de proteínas hipotalâmicas e de vias de sinalização relacionadas com o humor. Alterações nos níveis plasmáticos de corticosterona também podem contribuir para a patogênese dos transtornos psiquiátricos na prole F1. As perturbações comportamentais associadas ao humor induzidas por estresse pré-natal persistem na segunda geração de filhotes, mostrando os efeitos prejudiciais do estresse enfrentado por mulheres grávidas em seus filhos e netos ${ }^{8}$. Um trabalho constatou um aumento na predisposição genética ao abuso de álcool em pacientes com histórico familiar de transtornos afetivos ${ }^{38}$. Consequentemente, foi encontrada uma associação entre genes circadianos e o risco de abuso de álcool em pacientes do sexo masculino. Os resultados obtidos podem ser úteis para determinar o grupo de pacientes com alto risco alcoólatra, com a finalidade da preparação de um programa de prevenção adequado ${ }^{38}$.

\section{DISCUSSÃO}

Diante dos estudos avaliados, vale destacar os métodos e modelos utilizados, os transtornos psiquiátricos e os genes avaliados (família, funções e local de expressão desses genes), além das limitações e principais achados encontrados nos estudos. Na figura 2 abaixo, pode-se observar que 0 transtorno bipolar e o TDM consistiram nos distúrbios mais abordados entre as pesquisas consideradas no artigo. Esses transtornos estão relacionados e são condições neuropsiquiátricas complexas e debilitantes ${ }^{43}$. Ainda assim, os tratamentos recentes não são completamente efetivos e, apesar do notável progresso na compreensão da biologia neural, a etiofisiopatologia dessas condições ainda não foi totalmente esclarecida ${ }^{43}$. Até agora, a maioria dos estudos clínicos mostrou que pacientes com depressão e transtorno bipolar não possuem um resultado terapêutico satisfatório43. É importante ressaltar que a maioria dos artigos avaliou apenas um transtorno psiquiátrico, enquanto outros ampliaram as análises para dois ou três transtornos. 


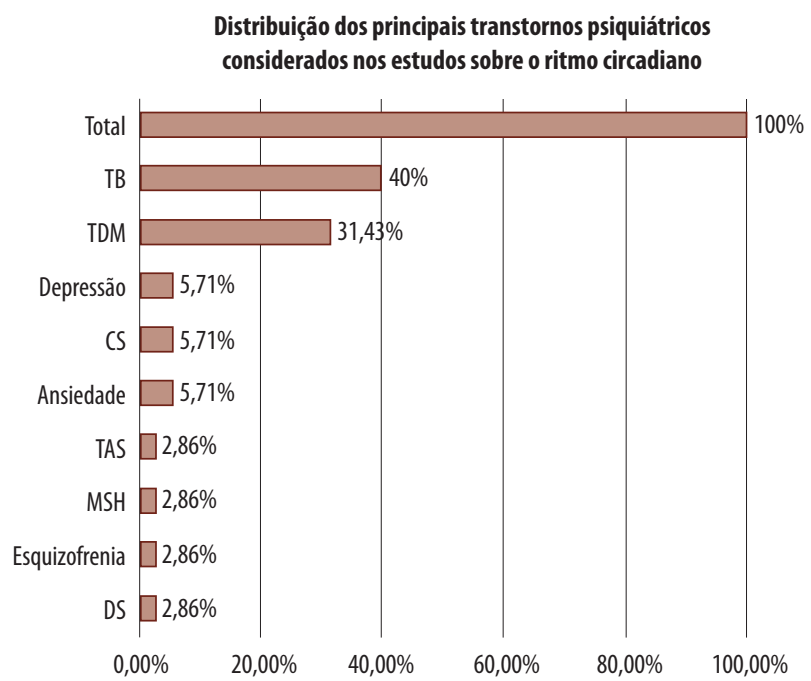

Figura 2. Distribuição dos principais transtornos psiquiátricos considerados nos estudos sobre ritmo circadiano. TB: transtorno bipolar; TDM: transtorno depressivo maior; TAS: transtorno afetivo sazonal; DS: distúrbios do sono; CS: comportamento suicida; MSH: mudanças sazonais de humor.

Adicionalmente, pode-se constatar que o gene PER foi o mais estudado entre os artigos analisados, provavelmente devido a sua significativa influência no transtorno bipolar e no transtorno depressivo maior, doenças que estão diretamente associadas ao comportamento suicida. O gene CLOCK foi o segundo mais avaliado nas pesquisas consideradas no artigo. Esses receptores possuem uma grande associação com o estado comportamental do indivíduo e com diversas condições tais como câncer, síndrome metabólica, obesidade e distúrbios do sono (Figura 3A). A maior parte dos artigos $(62,5 \%)$ avaliou dois ou mais genes, e apenas nove artigos $(37,5 \%)$ se restringiram a um gene.

Avaliou-se também os locais de expressão dos genes estudados (Figura 3B). Optamos por avaliar a localização apenas em humanos e no sistema nervoso; verificamos que o córtex cerebral foi região que mais se destacou, seguida do cerebelo. A área física compreendida pelo córtex cerebral, a sua complexidade e o seu envolvimento com diversas funções relevantes nos diversos transtornos psiquiátricos provavelmente justificam esse resultado. O córtex cerebral está principalmente envolvido com a tomada de decisões, pensamento subjetivo, avaliação das consequências de ação, percepção e atenção. Assim como o cérebro, o cerebelo também pode estar envolvido com o comportamento, cognição, humor e emoções ${ }^{44,45}$. Adicionalmente, assim como o córtex cerebral e o núcleo supraquiasmático, o cerebelo também está envolvido com o ritmo circadiano ${ }^{46}$. De fato, resultados preliminares sugerem o envolvimento dos genes circadianos em vários aspectos dos mecanismos fisiológicos e psicopatológicos do cérebro ${ }^{18}$.

A maioria dos genes avaliados é expressa como proteínas intracelulares, mas uma grande parte também é expressa como enzimas (Figura 3C), desempenhando funções cruciais na célula. A principal função observada foi a participação de alguns produtos gênicos no metabolismo da serotonina, incluindo o transporte, síntese e captação desse neurotransmissor essencial no sistema nervoso (Figura 3D). Os genes relógio SLC6A4, HTR2, ADRA2A e TPH, por exemplo, se destacaram nessas funções relacionadas com a serotonina e, portanto, podem estar envolvidos com diversos transtornos, tais como esquizofrenia, depressão, doença de Alzheimer e comportamento agressivo.

Os métodos, especialmente os ensaios de genotipagem, também foram avaliados (Figura 4A). Alguns artigos fizeram o uso de mais de dois métodos, por exemplo, Microarray, Western blot e RT-PCR ${ }^{28}$. Pode-se perceber que a PCR consistiu no método mais utilizado entre os artigos avaliados, em seguida esteve a PCR em tempo real (PCRq). As pesquisas que utilizaram PCR comum corresponderam a mais que o dobro das pesquisas que utilizaram a PCR em tempo real, provavelmente devido ao elevado custo da PCRq. Ambas as técnicas amplificam in vitro uma determinada região do DNA para análises específicas de um ou mais genes presentes nessa região, e na PCRq o resultado é visualizado em tempo real durante a amplificação da sequência de interesse. A PCR em tempo real possui a capacidade de gerar resultados quantitativos de maneira mais rápida, com maior precisão, sensibilidade e especificidade $^{47}$. O teste de genotipagem de polimorfismos nucleotídicos TaqMan SNP também consistiu em um método de escolha entre as pesquisas analisadas. O ensaio TaqMan SNP destaca-se, uma vez que as taxas de erro de genotipagem para todos os polimorfismos podem ser menores do que $1 \%{ }^{10-12}$. 

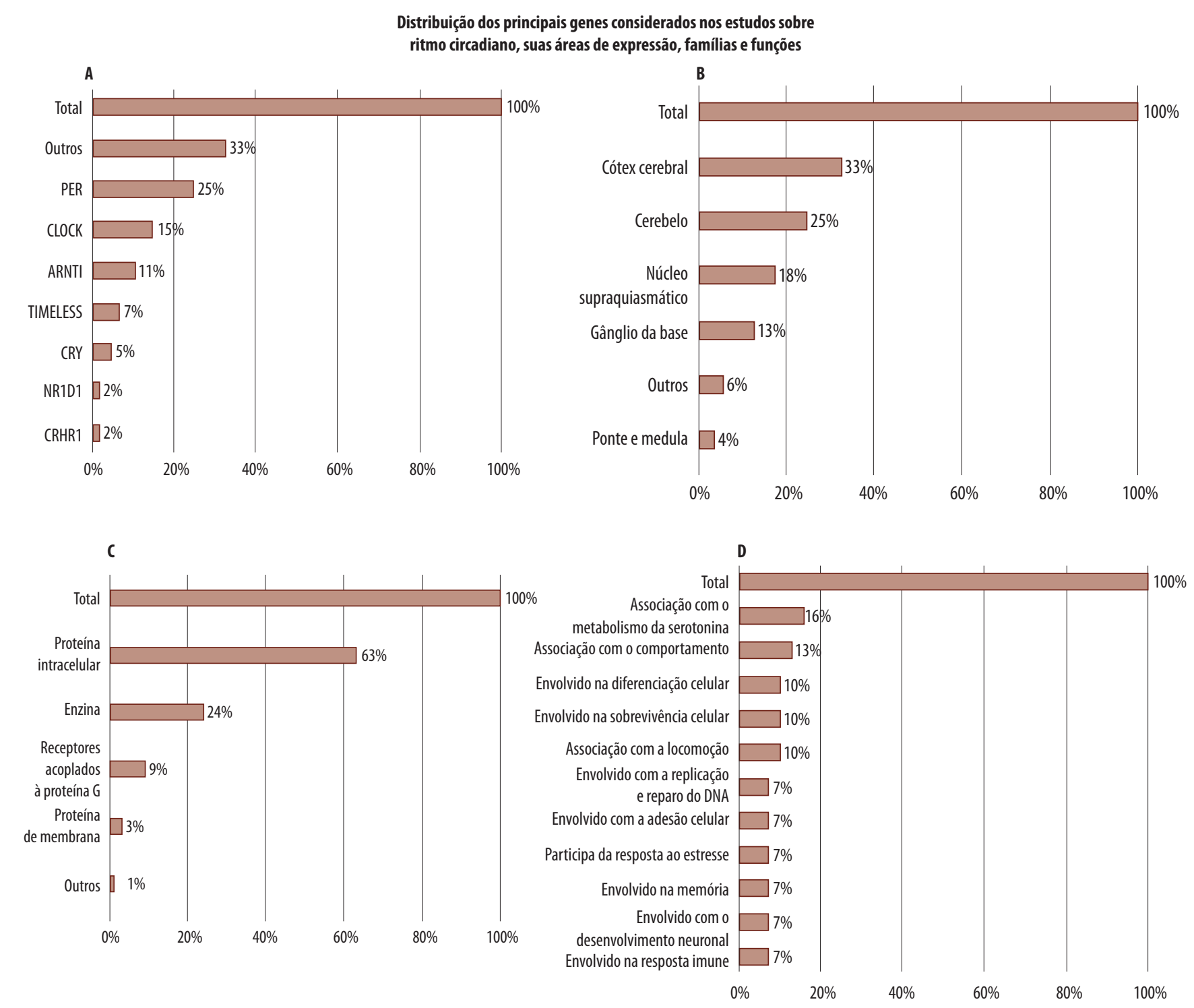

Figura 3. A) Distribuição dos principais genes considerados nos estudos sobre ritmo circadiano. B) Distribuição dos principais locais de expressão dos genes avaliados no sistema nervoso de humanos. C) Distribuição das principais famílias dos genes avaliados nos estudos sobre ritmo circadiano. D) Distribuição das principais funções dos genes avaliados nos estudos sobre ritmo circadiano.

A maioria dos estudos relacionados com a influência dos genes relógio nos transtornos psiquiátricos incluiu humanos (Figura 4B). Apenas três deles incluíram camundongos, todos da linhagem C57BL/6J, os quais são ideais para a realização dos testes comportamentais e análises genéticas. Já em relação aos participantes humanos envolvidos nas pesquisas, vale destacar que as nacionalidades polonesa e japonesa se destacaram nesses estudos envolvendo transtornos psiquiátricos (Figura 4C). De fato, de acordo com o repositório World Life Expectancy, a Polônia, o Japão e a Coreia do Sul apresentam elevadas taxam de transtornos mentais, em especial altos índices de suicídio ${ }^{48}$. Vale destacar também que a média de idade dos pacientes incluídos nas pesquisas foi de 45 anos. Já a média do número amostral foi de 1.050 participantes humanos e 127 animais.
Por fim, as principais limitações dos estudos também foram avaliadas com o objetivo de detectar os principais empecilhos encontrado pelos pesquisadores do ritmo circadiano (Material Suplementar). Considera-se que o pequeno número amostral correspondeu à principal limitação dos estudos (46\%), em seguida estavam as análises limitadas de genes ou dos polimorfismos estudados, provavelmente devido ao alto custo dos métodos de genotipagem. A ausência de entrevistas também consistiu em uma limitação encontrada por alguns autores; a entrevista por si poderia fornecer algumas informações relevantes que deixaram de ser consideradas em alguns artigos. Vale ressaltar que um questionário não substitui uma entrevista diagnóstica para avaliar sintomas depressivos, por exemplo. 
Distribuição dos principais métodos, modelos e nacionalidades dos participantes

considerados e incluídos nos estudos sobre ritmo circadiano
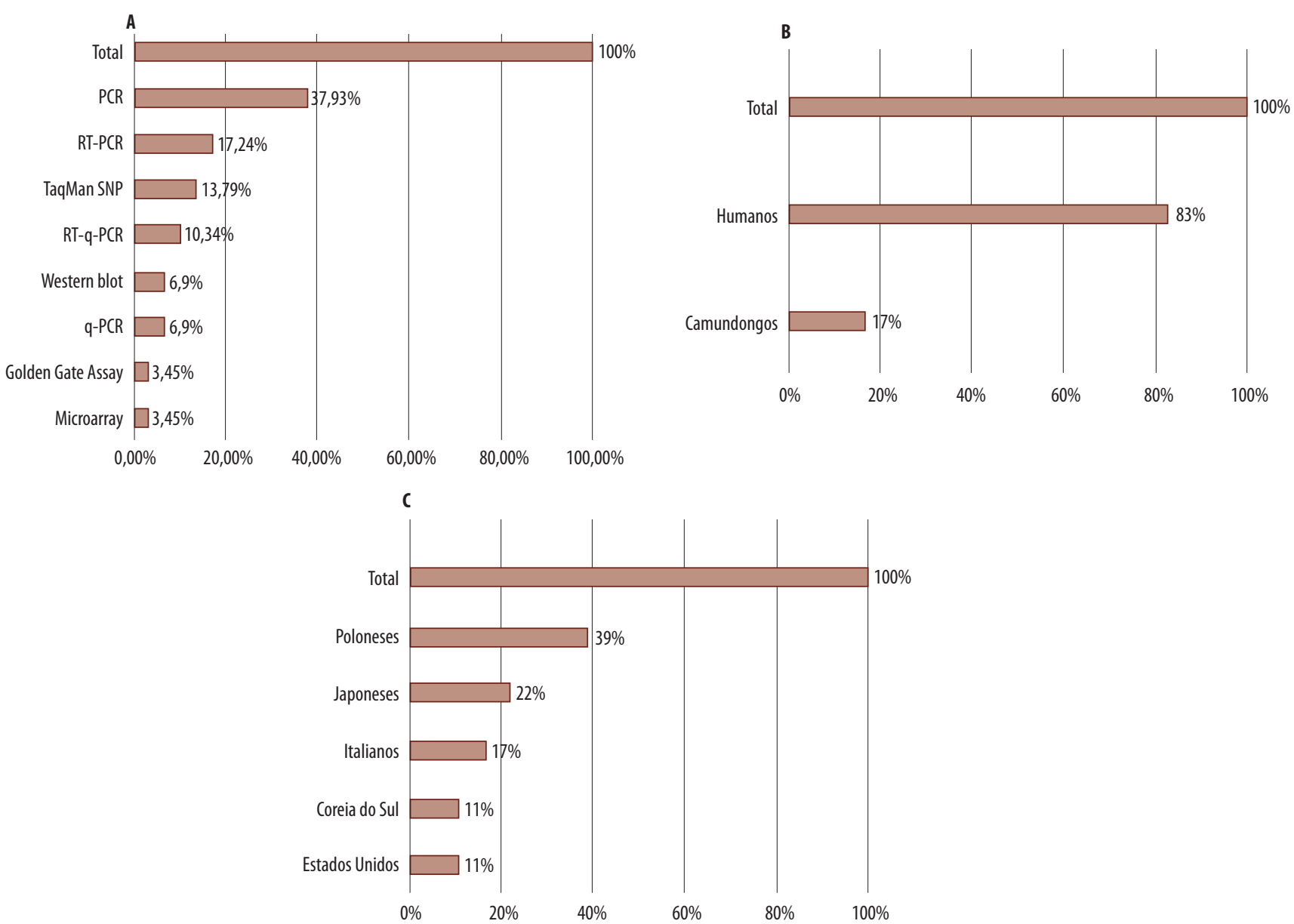

Figura 4. A) Distribuição dos principais métodos utilizados nos estudos sobre ritmo circadiano. B) Distribuição dos principais modelos utilizados nos estudos sobre ritmo circadiano. C) Distribuição das nacionalidades dos participantes incluídos nos estudos sobre ritmo circadiano.

Em relação às limitações da nossa revisão, em especial, devemos destacar a pequena quantidade de artigos contendo todas as informações de interesse. Nesse sentido, foi necessário incluir neste trabalho apenas os 24 estudos que possuíam todos os dados utilizados para a elaboração dos gráficos e tabelas. Adicionalmente, uma análise aprofundada dos genes circadianos envolvidos com os transtornos psiquiátricos em bancos de dados específicos, tais como Kyoto Encyclopedia of Genes and Genomes (KEGG) e String Data Base, poderia ser relevante nesse contexto. Dessa forma, acreditamos que seria importante a inclusão de tais ferramentas em futuras revisões sistemáticas sobre o tema. Em resumo, esta revisão permitiu uma percepção global sobre os genes relógio envolvidos em transtornos psiquiátricos (Figura 5), por meio da utilização de uma metodologia sistemática. A maioria dos estudos analisados mostrou alguma perspectiva de aplicação clínica. Os artigos apresentam diferentes métodos de genotipagem, com o objetivo comum de detectar a influência de genes e polimorfismos específicos em transtornos psiquiátricos.

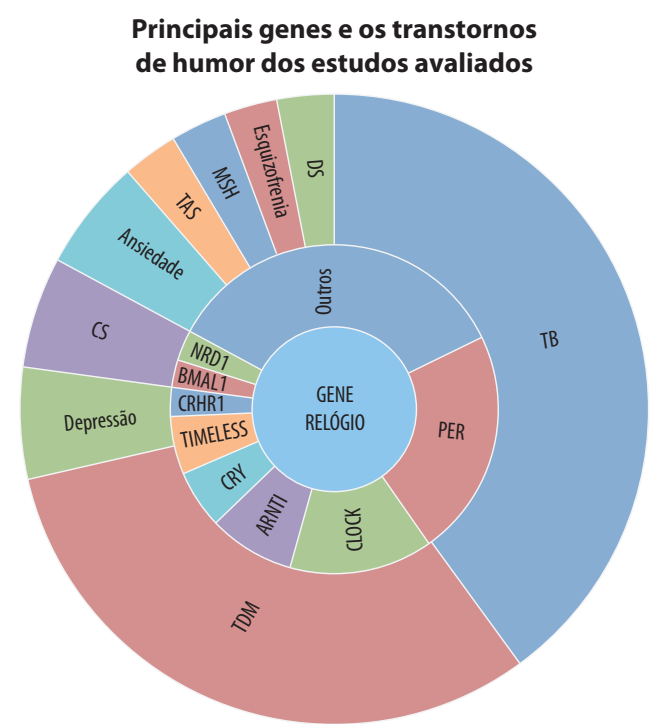

Figura 5. A figura resume os genes e os transtornos de humor dos estudos avaliados. Os genes e os transtornos de humor não se correlacionam na imagem. TB: transtorno bipolar; TDM: transtorno depressivo maior; TAS: transtorno afetivo sazonal; DS: distúrbios do sono; CS: comportamento suicida; MSH: mudança sazonal de humor. 


\section{CONCLUSÃO}

O presente estudo compilou pesquisas científicas relacionadas à regulação molecular dos ritmos circadianos e as suas possíveis influências em transtornos psiquiátricos. Por meio da análise dos artigos, foi possível observar que, apesar de recente, a produção científica sobre o tema tem ganhado maiores proporções, criando, assim, um campo de estudo cada vez mais consolidado, com informações relevantes para o tratamento, diagnóstico e prevenção de transtornos psiquiátricos, especialmente o transtorno depressivo e o transtorno bipolar. Este trabalho constatou que o transtorno bipolar consistiu no transtorno psiquiátrico mais abordado entre as pesquisas avaliadas. Adicionalmente, o gene PER foi o mais estudado, a PCR comum mostrou-se ser o método mais utilizado e o número amostral, a principal limitação dos estudos. Estudos experimentais e revisões relacionados ao ritmo circadiano devem ser realizados periodicamente, uma vez que o avanço nas pesquisas em cronobiologia molecular tem alto teor de aplicabilidade na medicina preventiva.

\section{CONTRIBUIÇÕES INDIVIDUAIS}

Cibele Monteiro - Contribuiu substancialmente para a concepção e design; contribuiu substancialmente para análise e interpretação dos dados; contribuiu substancialmente para redigir o artigo.

Emanuella Tavares - Contribuiu substancialmente para a concepção e design; contribuiu substancialmente para análise e interpretação dos dados; contribuiu substancialmente para redigir o artigo.

Alice Câmara - Contribuiu substancialmente para análise e interpretação dos dados; contribuiu substancialmente para redigir o artigo ou revisá-lo criticamente para conteúdo intelectual importante.

Jonas Nobre - Contribuiu substancialmente para revisar criticamente o artigo para conteúdo intelectual importante e deu a aprovação final da versão a ser publicada.

\section{CONFLITOS DE INTERESSE}

Os autores declaram que não existe conflito de interesses em relação à publicação deste documento.

\section{REFERÊNCIAS}

1. DeCoursey PJ, Krulas JR. Behavior of SCN-lesioned chipmunks in natural habitat: a pilot study. J Biol Rhythms. 1998;13(3):229-44.

2. Coomans (P, Ramkisoensing A, Meijer JH. The suprachiasmatic nuclei as a seasonal clock. Front Neuroendocrinol. 2015;37:29-42
3. Pedrazzoli M. Moléculas que marcam o tempo: implicaçōes para os fenótipos circadianos e transtornos do humor. Rev Bras Psiquiatr. 2009;31(1).

4. Ralph MR, Foster RG, Davis FC, Menaker M. Transplanted suprachiasmatic nucleus determines circadian period. Science. 1990;247(4945): 975-8.

5. Krieger DT. The Clocks that Time Us: (Physiology of the Circadian Timing System). Psychosom Med. 1982:44(6):559-60.

6. DeCoursey PJ. Overview of biological timing from unicells to humans. In: Dunlap JC, Loros JJ, DeCoursey PJ, eds. Chronobiology: biological timekeeping. Massachusetts: Sinauer Associates Inc.; 2004. p. 3-24

7. Dmitrzak-Wẹglarz M, Pawlak J, Wiłkość M, Miechowicz I, Maciukiewicz M, Ciarkowska W, et al. Chronotype and sleep quality as a subphenotype in association studies of clock genes in mood disorders. Acta Neurobiol Exp (Wars). 2016;76:32-42.

8. Zhang P, Li G, Li H, Tan X, Cheng HYM. Environmental perturbation of the circadian clock during pregnancy leads to transgenerational mood disorder-like behaviors in mice. Sci Rep. 2017;7(1):12641.

9. Zhao C, Gammie SC. The circadian gene Nr1d1 in the mouse nucleus accumbens modulates sociability and anxiety-related behaviour. Eur J Neurosci. 2018;48(3):1924-43.

10. Pawlak J, Dmitrzak-Weglarz M, Skibińska M, Szczepankiewicz A, Leszczyńska-Rodziewicz A, Rajewska-Rager A, et al. Suicide attempts and clinical risk factors in patients with bipolar and unipolar affective disorders. Gen Hosp Psychiatry. 2013;35(4):427-32.

11. Pawlak J, Dmitrzak-Węglarz M, Skibińska M, Szczepankiewicz A, Leszczyńska-Rodziewicz A, Rajewska-Rager A, et al. Suicide attempts and clinical risk factors in patients with bipolar and unipolar affective disorders. Gen Hosp Psychiatry. 2013;35(4):309-13.

12. Pawlak J, Dmitrzak-Weglarz M, Wilkosc M, Szczepankiewicz A, Leszczynska-Rodziewicz A, Zaremba D, et al. Suicide behavior as a quantitative trait and its genetic background. J Affect Disord. 2016;206:241-50

13. Baldessarini RJ, Hennen J. Genetics of suicide: an overview. Harv Rev Psychiatry. 2004;12(1):1-13.

14. van Heeringen K. Stress-diathesis model of suicidal behavior. In: Dwivedi Y, ed. The neurobiological basis of suicide. Boca Raton (FL): CRC Press/Taylor \& Francis; 2012.

15. Lester D. Morningness - eveningness, current depression, and past suicidality. Psychol Rep. 2015;116(2):331-6.

16. Mondin TC, de Azevedo Cardoso T, de Mattos Souza LD, Jansen K, da Silva Magalhães PV, Kapczinski F, et al. Mood disorders and biological rhythms in young adults: a large population-based study. J Psychiatr Res. 2017;84:98-104.

17. Parekh PK, Becker-Krail D, Sundaravelu P, Ishigaki S, Okado H, Sobue G, et al. Altered GluA1 (Gria1) function and accumbal synaptic plasticity in the Clock $\Delta 19$ model of bipolar mania. Biol Psychiatr. 2018;84(11):817-26

18. Artioli P, Lorenzi C, Pirovano A, Serretti A, Benedetti F, Catalano M, et al. How do genes exert their role? Period 3 gene variants and possible influences on mood disorder phenotypes. Eur Neuropsychopharmacol. 2007;17(9):587-94.

19. Asher G, Gatfield D, Stratmann M, Reinke H, Dibner C, Kreppel F, et al. SIRT1 regulates circadian clock gene expression through PER2 deacetylation. Cell. 2008;134(2):317-28.

20. Nakahata Y, Kaluzova M, Grimaldi B, Sahar S, Hirayama J, Chen D, et al. The NAD+dependent deacetylase SIRT1 modulates CLOCK-mediated chromatin remodeling and circadian control. Cell. 2008;134(2):329-40.

21. Nakahata Y, Sahar S, Astarita G, Kaluzova M, Sassone-Corsi P. Circadian control of the NAD+ salvage pathway by CLOCK-SIRT1. Science. 2009;324(5927):654-7.

22. Ramsey KM, Yoshino J, Brace CS, Abrassart D, Kobayashi Y, Marcheva B, et al. Circadian clock feedback cycle through NAMPT-mediated NAD+ biosynthesis. Science. 2009;324(5927):651-4.

23. Wijnen H. A circadian loop asSIRTs itself. Science. 2009;324(5927):598-9.

24. Kishi T, Yoshimura R, Kitajima T, Okochi T, Okumura T, Tsunoka T, et al. SIRT1 gene is associated with major depressive disorder in the Japanese population. J Affect Disord. 2010;126(1-2):167-73

25. Kim HI, Lee HJ, Cho CH, Kang SG, Yoon HK, Park YM, et al. Association of CLOCK, ARNTL, and NPAS2 gene polymorphisms and seasonal variations in mood and behavior. Chronobiol Int. 2015:32(6):785-91.

26. Shiino Y, Nakajima S, Ozeki Y, Isono T, Yamada N. Mutation screening of the human period 2 gene in bipolar disorder. Neurosci Lett. 2003:338(1):82-4 
27. Bailer $U$, Wiesegger $G$, Leisch F, Fuchs $K$, Leitner I, Letmaier $M$, et al. No association of clock gene T3111C polymorphism and affective disorders. Eur Neuropsychopharmacol. 2005;15(1):51-5.

28. Kato T, Ishiwata M, Yamada K, Kasahara T, Kakiuchi C, Iwamoto K, et al. Behavioral and gene expression analyses of Wfs 1 knockout mice as a possible animal model of mood disorder. Neurosci Res. 2008;61(2):143-58.

29. Kishi T, Kitajima T, Ikeda M, Yamanouchi Y, Kinoshita Y, Kawashima K, et al. Association analysis of nuclear receptor Rev-erb alpha gene (NR1D1) with mood disorders in the Japanese population. Neurosci Res. 2008;62(4):211-5.

30. Dallaspezia S, Lorenzi C, Pirovano A, Colombo C, Smeraldi E, Benedetti F. Circadian clock gene Per3 variants influence the postpartum onset of bipolar disorder. Eur Psychiatry. 2011;26(3):138-40.

31. Wilkosc M, Wegalrz M, Maciukiewicz M, Pawlak J, Leszczynska-Rodziewicz A, Hauser J. P. 2. b. 019 Clock gene polymorphisms and haplotypes in mood disorder in a Polish cohort. Eur Neuropsychopharmacol. 2013;23:S329-30.

32. Szczepankiewicz A, Leszczynska-Rodziewicz A, Pawlak J, Rajewska-Rager A, Wilkosc M, Zaremba D. Epistatic interaction between CRHR1 and AVPR1b variants as a predictor of major depressive disorder. Psychiatr Genet. 2013;23(6):239-46.

33. Hua P, Liu W, Chen D, Zhao Y, Chen L, Zhang N, et al. Cry1 and Tef gene polymorphisms are associated with major depressive disorder in the Chinese population. J Affect Disord. 2014;157:100-3.

34. Nováková M, Praško J, Látalová K, Sládek M, Sumová A. The circadian system of patients with bipolar disorder differs in episodes of mania and depression. Bipolar Disord. 2015;17(3):303-14

35. Rybakowski JK, Dmitrzak-Weglarz M, Dembinska-Krajewska D, Hauser J, Akiskal KK, Akiskal HH. Polymorphism of circadian clock genes and temperamental dimensions of the TEMPS-A in bipolar disorder. J Affect Disord. 2014;159:80-4.

36. Maglione JE, Nievergelt CM, Parimi N, Evans DS, Ancoli-Israel S, Stone KL, et al. Associations of PER3 and RORA circadian gene polymorphisms and depressive symptoms in older adults. Am J Geriatr Psychiatry. 2015;23(10):1075-87.
37. Suzuki M, Dallaspezia S, Locatelli C, Lorenzi C, Uchiyama M, Colombo C, et al. CLOCK gene variants associated with the discrepancy between subjective and objective severity in bipolar depression. J Affect Disord. 2017;210:14-8.

38. Banach E, Pawlak J, Kapelski P, Szczepankiewicz A, Rajewska-Rager A, Skibinska M, et al. Clock genes polymorphisms in male bipolar patients with comorbid alcohol abuse. J Affect Disord. 2018;241:142-6.

39. Matsunaga $S$, Ikeda M, Kishi T, Fukuo Y, Aleksic B, Yoshimura R, et al. An evaluation of polymorphisms in casein kinase 1 delta and epsilon genes in major psychiatric disorders. Neurosci Lett. 2012;529(1):66-9.

40. Pawlak J, Szczepankiewicz A, Kapelski P, Rajewska-Rager A, Slopien A, Skibinska M, et al. Suicidal behavior in the context of disrupted rhythmicity in bipolar disorder Complementary research of clock genes with suicide risks factors and course of disease. Psychiatry Res. 2017;257:446-9.

41. Yang SY, Baek JH, Cho Y, Cho EY, Choi Y, Kim Y, et al. Effects of genetic variants of ST8SIA2 and NCAM1 genes on seasonal mood changes and circadian preference in the general population. Chronobiol Int. 2018;35(3):405-15.

42. Liberman AR, Halitjaha L, Ay A, Ingram KK. Modeling Strengthens Molecular Link between Circadian Polymorphisms and Major Mood Disorders. J Biol Rhythms. 2018;33(3):318-36.

43. Cui R. A systematic review of depression. Curr Neuropharmacol. 2015;13(4):480.

44. Minichino A, Bersani FS, Trabucchi G, Albano G, Primavera M, Delle Chiaie R, et al. The role of cerebellum in unipolar and bipolar depression: a review of the main neurobiological findings. Riv Psichiatr. 2014;49(3):124-31.

45. Camara AB. Receptores neurais e a doença de Alzheimer: uma revisão sistemática da literatura sobre as famílias de receptores mais associadas a doença, suas funções e áreas de expressão. J Bras Psiquiatr. 2019;68(3):159-74.

46. Bering T, Hertz H, Rath M. Rhythmic release of corticosterone induces circadian clock gene expression in the cerebellum. Neuroendocrinology. 2019.

47. Pfaffl MW. A new mathematical model for relative quantification in real-time RT-PCR. Nucleic Acids Res. 2001;29(9):e45

48. World Health Organization. World Health Rankings: Suicide. Disponível em: https://www worldlifeexpectancy.com/cause-of-death/suicide/by-country/. Acesso em: 28 set. 2019.

\section{MATERIAL SUPLEMENTAR}

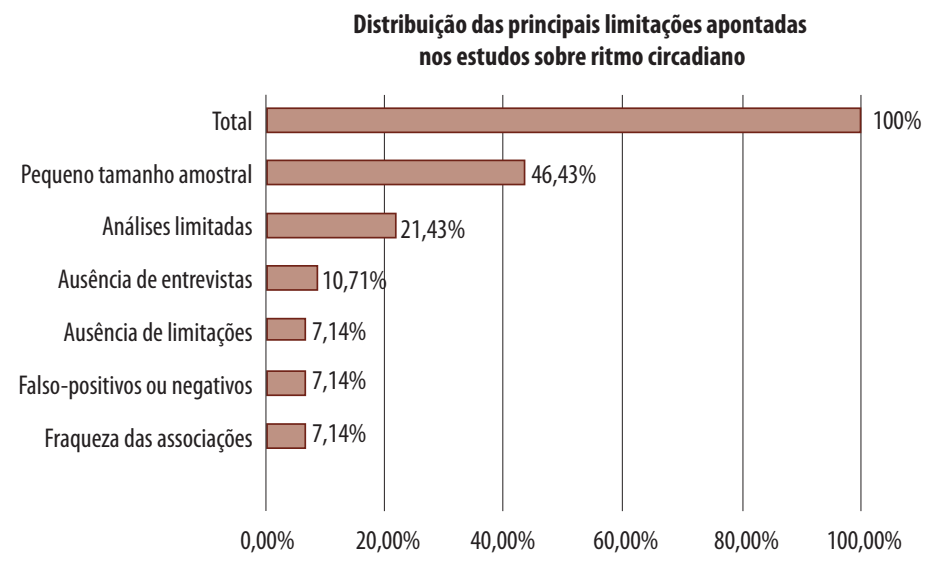

